Chapter 13

\title{
Impact of Systemic Insecticides on Organisms and Ecosystems
}

\author{
Francisco Sánchez-Bayo, Henk A. Tennekes and \\ Koichi Goka
}

Additional information is available at the end of the chapter

http://dx.doi.org/10.5772/52831

\section{Introduction}

Systemic insecticides were first developed in the 1950s, with the introduction of soluble organophosphorus (OP) compounds such as dimethoate, demeton-S-methyl, mevinphos and phorate. They were valuable in controlling sucking pests and burrowing larvae in many crops, their main advantage being their translocation to all tissues of the treated plant. Systemic carbamates followed in the 1960s with aldicarb and carbofuran. Since then, both insecticidal classes comprise a large number of broad-spectrum insecticides used in agriculture all over the world. Nowadays, OPs are the most common pesticides used in tropical, developing countries such as the Philippines and Vietnam, where 22 and $17 \%$ of the respective agrochemicals are 'extremely hazardous' [126], i.e. classified as WHO class I. Systemic insect growth regulators were developed during the 1980-90s, and comprise only a handful of compounds, which are more selective than their predecessors. Since 1990 onwards, cartap, fipronil and neonicotinoids are replacing the old hazardous chemicals in most developed and developing countries alike [137].

Through seed coatings and granular applications, systemic insecticides pose minimal risk of pesticide drift or worker exposure in agricultural, nurseries and urban settings. Neonicotinoids and fipronil are also preferred because they appear to be less toxic to fish and terrestrial vertebrates. Initially proposed as environmentally friendly agrochemicals [129], their use in Integrated Pest Management (IPM) programs has been questioned by recent research that shows their negative impact on predatory and parasitic agents [221, 258, 299]. New formulations have been developed to optimize the bioavailability of neonicotinoids, as well as combined formulations with pyrethroids and other insecticides with the aim of broadening the insecticidal spectrum and avoid resistance by pests [83]. Indeed, as with any other chem- 
ical used in pest control, resistance to imidacloprid by whitefly (Bemisia tabaci), cotton aphids (Aphis gossypii) and other pests is rendering ineffective this and other neonicotinoids such as acetamiprid, thiacloprid and nitenpyram [247, 269].

This chapter examines the negative impacts that systemic insecticides have on organisms, populations and ecosystems. The efficacy of these products in controlling the target pests is assumed and not dealt with here - only the effects on non-target organisms and communities are considered.

\section{Exposure to systemic insecticides}

Unlike typical contact insecticides, that are usually taken up through the arthropod's cuticle or skin of animals, systemic insecticides get into the organisms mainly through feeding on the treated plants or contaminated soil. Thus, monocrotophos and imidacloprid are more lethal to honey bees (Apis mellifera) through feeding than contact exposure [143]. Residual or contact exposure affects also some pests and non-target species alike.

Systemic insecticides are applied directly to the crop soil and seedlings in glasshouses using flowable solutions or granules, and often as seed-dressings, with foliar applications and drenching being less common. Being quite water soluble (Table 1), these insecticides are readily taken up by the plant roots or incorporated into the tissues of the growing plants as they develop, so the pests that come to eat them ingest a lethal dose and die. Sucking insects in particular are fatally exposed to systemic insecticides, as sap carries the most concentrated fraction of the poisonous chemical for a few weeks [124], whereas leaf-eating species such as citrus thrips and red mites may not be affected [30]. Systemic insecticides contaminate all plant tissues, from the roots to leaves and flowers, where active residues can be found up to 45-90 days [175, 187], lasting as long as in soil. Thus, pollen and nectar of the flowers get contaminated [33], and residues of imidacloprid and aldicarb have been found at levels above $1 \mathrm{mg} / \mathrm{kg}$ in the United States [200]. Guttation drops, in particular, can be contaminated with residues as high as 100-345 mg/L of neonicotinoids during 10-15 days following application [272]. Because these insecticides are incorporated in the flesh of fruits, the highly poisonous aldicarb is prohibited in edible crops such as watermelons, as it has caused human poisoning [106].

As with all poisonous chemicals spread in the environment, not only the target insect pests get affected: any other organism that feeds on the treated plants receives a dose as well, and may die or suffer sublethal effects. For example, uptake of aldicarb by plants and worms results in contamination of the vertebrate fauna up to 90 days after application [41], and honey bees may collect pollen contaminated with neonicotinoids to feed their larvae, which are thus poisoned and die [125]. Newly emerged worker bees are most susceptible to insecticides, followed by foraging workers, while nursery workers are the least susceptible within $72 \mathrm{~h}$ of treatment [80]. Insects and mites can negatively be affected by systemic insecticides whenever they feed on: 
1. pollen, nectar, plant tissue, sap or guttation drops contaminated with the active ingredient (primary poisoning);

2. prey or hosts that have consumed leaves contaminated with the active ingredient (secondary poisoning).

Parasitoids may be indirectly affected because foliar, drench or granular applications may decrease host population to levels that are not enough to sustain them. Furthermore, host quality may be unacceptable for egg laying by parasitoid females [54]. Small insectivorous animals (e.g. amphibians, reptiles, birds, shrews and bats) can also suffer from primary poisoning if the residual insecticide or its metabolites in the prey are still active. It should be noticed that some metabolites of imidacloprid, thiamethoxam, fipronil and 50\% of carbamates are as toxic as the parent compounds [29]. Thus, two species of predatory miridbugs were negatively affected by residues and metabolites of fipronil applied to rice crops [159]. However, since systemic insecticides do not bioaccumulate in organisms, there is little risk of secondary poisoning through the food chain.

Apart from feeding, direct contact exposure may also occur when the systemic insecticides are sprayed on foliage. In these cases, using a silicone adjuvant (Sylgard 309) reduces the contact exposure of honey bees to carbofuran, methomyl and imidacloprid, but increases it for fipronil [184]. In general the susceptibility of bees to a range of insecticides is: wild bees > honey bee $>$ bumble bee [185]. In reality a combination of both contact and feeding exposure occurs, which is more deadly than either route of exposure alone [152, 218].

In soil, residues of acephate and methomyl account for most of the cholinesterase inhibition activity found in mixtures of insecticides [233]. Fortunately, repeated applications of these insecticides induces microbial adaptation, which degrade the active compounds faster over time [250]. Degradation of carbamates and OPs in tropical soils or vegetation is also faster than on temperate regions, due mainly to microbial activity [46]. Some neonicotinoids are degraded by soil microbes [172], and the yeast Rhodotorula mucilaginosa can degrade acetamiprid but none of the other neonicotinoids [63], which are quite persistent in this media (Table 2).

\begin{tabular}{lllllll}
\hline Chemical & Group & $\begin{array}{l}\text { Vapour Pressure } \\
\left(\mathbf{m P a}, \mathbf{2 5}^{\circ} \mathbf{C}\right)\end{array}$ & $\begin{array}{l}\text { Solubilityin } \\
\text { water }(\mathbf{m g} / \mathbf{L})\end{array}$ & Log Kow\# & $\begin{array}{l}\text { GUS } \\
\text { index* }\end{array}$ & Leaching potential \\
\hline aldicarb & $\mathrm{C}$ & 3.87 & 4930 & 1.15 & 2.52 & moderate \\
\hline bendiocarb & $\mathrm{C}$ & 4.6 & 280 & 1.72 & 0.77 & low \\
\hline butocarboxim & $\mathrm{C}$ & 10.6 & 35000 & 1.1 & 1.32 & low \\
\hline butoxycarboxim & $\mathrm{C}$ & 0.266 & 209000 & -0.81 & $\mathbf{4 . 8 7}$ & high \\
\hline carbofuran & $\mathrm{C}$ & 0.08 & 322 & 1.8 & $\mathbf{3 . 0 2}$ & high \\
\hline ethiofencarb & $\mathrm{C}$ & 0.5 & 1900 & 2.04 & $\mathbf{3 . 5 8}$ & high \\
\hline methomyl & $\mathrm{C}$ & 0.72 & 55000 & 0.09 & 2.20 & marginal \\
\hline oxamyl & $\mathrm{C}$ & 0.051 & 148100 & -0.44 & 2.36 & moderate \\
\hline pirimicarb & $\mathrm{C}$ & 0.43 & 3100 & 1.7 & 2.73 & moderate
\end{tabular}




\begin{tabular}{|c|c|c|c|c|c|c|}
\hline Chemical & Group & $\begin{array}{l}\text { Vapour Pressure } \\
\left(\mathrm{mPa}, 25^{\circ} \mathrm{C}\right)\end{array}$ & $\begin{array}{l}\text { Solubilityin } \\
\text { water (mg/L) }\end{array}$ & Log Kow\# & $\begin{array}{l}\text { GUS } \\
\text { index* }\end{array}$ & Leaching potential \\
\hline thiodicarb & $C$ & 5.7 & 22.2 & 1.62 & -0.24 & low \\
\hline thiofanox & C & 22.6 & 5200 & 2.16 & 1.67 & low \\
\hline triazamate & $\mathrm{C}$ & 0.13 & 433 & 2.59 & -0.9 & low \\
\hline cartap & $D$ & $1.0 \times 10^{-10}$ & 200000 & -0.95 & - & high \\
\hline halofenozide & IGR & $<0.013$ & 12.3 & 3.34 & 3.75 & high \\
\hline hexaflumuron & IGR & 0.059 & 0.027 & 5.68 & -0.03 & unlikely to leach \\
\hline novaluron & IGR & 0.016 & 0.003 & 4.3 & 0.03 & low \\
\hline teflubenzuron & IGR & 0.000013 & 0.01 & 4.3 & -0.82 & low \\
\hline acetamiprid & $\mathrm{N}$ & 0.000173 & 2950 & 0.8 & 0.94 & low \\
\hline clothianidin & $\mathrm{N}$ & $2.8 \times 10^{-8}$ & 340 & 0.905 & 4.91 & high \\
\hline dinotefuran & $\mathrm{N}$ & 0.0017 & 39830 & -0.549 & 4.95 & high \\
\hline imidacloprid & $\mathrm{N}$ & 0.0000004 & 610 & 0.57 & 3.76 & high \\
\hline nitenpyram & $\mathrm{N}$ & 0.0011 & 590000 & -0.66 & 2.01 & moderate \\
\hline thiacloprid & $\mathrm{N}$ & 0.0000003 & 184 & 1.26 & 1.44 & unlikely to leach \\
\hline thiamethoxam & $\mathrm{N}$ & 0.0000066 & 4100 & -0.13 & 3.82 & high \\
\hline acephate & OP & 0.226 & 790000 & -0.85 & 1.14 & low \\
\hline demeton-S-methyl & OP & 40 & 22000 & 1.32 & 0.88 & low \\
\hline dicrotophos & OP & 9.3 & 1000000 & -0.5 & 3.08 & high \\
\hline dimethoate & OP & 0.25 & 39800 & 0.704 & 1.06 & low \\
\hline disulfoton & OP & 7.2 & 25 & 3.95 & 1.29 & low \\
\hline fenamiphos & OP & 0.12 & 345 & 3.3 & -0.11 & low \\
\hline fosthiazate & OP & 0.56 & 9000 & 1.68 & 2.48 & moderate \\
\hline heptenophos & OP & 65 & 2200 & 2.32 & 0.26 & low \\
\hline methamidophos & OP & 2.3 & 200000 & -0.79 & 2.18 & moderate \\
\hline mevinphos & OP & 17 & 600000 & 0.127 & 0.19 & low \\
\hline monocrotophos & OP & 0.29 & 818000 & -0.22 & 2.3 & moderate \\
\hline omethoate & OP & 3.3 & 10000 & -0.74 & 2.73 & moderate \\
\hline oxydemeton-methyl & OP & 2.0 & 1200000 & -0.74 & 0.0 & low \\
\hline phorate & OP & 112 & 50 & 3.86 & 1.4 & low \\
\hline phosphamidon & OP & 2.93 & 1000000 & 0.79 & 2.39 & moderate \\
\hline thiometon & OP & 39.9 & 200 & 3.15 & 0.37 & low \\
\hline vamidothion & OP & $1.0 \times 10^{-10}$ & 4000000 & -4.21 & 0.55 & low \\
\hline fipronil & $\mathrm{PP}$ & 0.002 & 3.78 & 3.75 & 2.45 & moderate \\
\hline
\end{tabular}

Table 1. Physicochemical properties of systemic insecticides. $C=$ carbamates; $D=$ dithiol; IGR = Insect growth regulator; $\mathrm{N}=$ neonicotinoid; $\mathrm{OP}=$ organophosphate; $\mathrm{PP}=$ phenylpyrazole

\# Partition coefficients between n-octanol and water (Kow) indicate bioaccumulation potential when Log Kow $>4$.

*The Groundwater Ubiquity Score (GUS) is calculated using soil half-life (DT50) and organic-carbon sorption constant (Koc) as follows: GUS = $\log (\mathrm{DT} 50) \times(4-\log \mathrm{Koc})$. A compound is likely to leach if GUS > 2.8 and unlikely to leach when GUS $<1.8$; other values in between indicate that leaching potential is marginal. 


\begin{tabular}{|c|c|c|c|c|c|}
\hline \multirow[t]{2}{*}{ Chemical } & \multirow[t]{2}{*}{ Group } & \multicolumn{2}{|l|}{ Water } & \multicolumn{2}{|l|}{ Field } \\
\hline & & Photolysis (pH 7) & Hydrolysis (pH 5-7) & Water-sediment & Soil (range) \\
\hline aldicarb & C & 8 & 189 & 6 & $10(1-60)$ \\
\hline bendiocarb & $C$ & 13 & 25 & 2 & $4(3-20$ \\
\hline butocarboxim & $C$ & Sta ble & stable & - & $4(1-8)$ \\
\hline butoxycarboxim & $C$ & Stable & $18(510-16)$ & - & 42 \\
\hline carbofuran & $C$ & 71 & $37(46-0.1)$ & 9.7 & $14(1-60)$ \\
\hline ethiofencarb & $C$ & - & 16 & 52 & $37(34-131)$ \\
\hline methomyl & $C$ & Stable & stable & 4 & $7(5-30)$ \\
\hline oxamyl & $C$ & 7 & 8 & $<1$ & 11 \\
\hline pirimicarb & $C$ & 6 & stable & 195 & $9(5-13)$ \\
\hline thiodicarb & C & 9 & $30(69-0.3)$ & $<1$ & $18(1-45)$ \\
\hline thiofanox & $C$ & 1 & 30 & - & $4(2-6)$ \\
\hline triazamate & C & 301 & 2 & $<1$ & $<1$ \\
\hline cartap & $\mathrm{D}$ & - & - & - & 3 \\
\hline halofenozide & IGR & 10 & stable & - & $219(60-219)$ \\
\hline hexaflumuron & IGR & 6 & stable & - & 170 \\
\hline novaluron & IGR & Stable & stable & 18 & $97(33-160)$ \\
\hline teflubenzuron & IGR & 10 & stable & 16 & $14(9-16)$ \\
\hline acetamiprid & $\mathrm{N}$ & 34 & $420^{a}$ & - & $3(2-20)$ \\
\hline clothianidin & $\mathrm{N}$ & 0.1 & $14^{a}$ & 56 & $545(13-1386)$ \\
\hline dinotefuran & $\mathrm{N}$ & 0.2 & stable & - & $82(50-100)$ \\
\hline imidacloprid & $\mathrm{N}$ & 0.2 & $\sim 365^{a}$ & 129 & $191(104-228)$ \\
\hline nitenpyram & $\mathrm{N}$ & NA & $2.9^{a}$ & - & 8 \\
\hline thiacloprid & $\mathrm{N}$ & stable & stable & 28 & $16(9-27)$ \\
\hline thiamethoxam & $\mathrm{N}$ & 2.7 & $11.5^{\mathrm{a}}$ & 40 & $50(7-72)$ \\
\hline acephate & OP & 2 & 50 & - & 3 \\
\hline demeton-S-methyl & $\mathrm{OP}$ & - & $56(63-8)$ & - & 2.7 \\
\hline dicrotophos & OP & - & - & - & 28 \\
\hline dimethoate & OP & 175 & $68(156-4)$ & 15 & $7(5-10)$ \\
\hline disulfoton & OP & 4 & 300 & 15 & 30 \\
\hline fenamiphos & OP & $<1$ & 304 & 60 & $2(1-50)$ \\
\hline fosthiazate & OP & Stable & $104(178-3)$ & 51 & $13(9-17)$ \\
\hline heptenophos & OP & - & 13 & 7 & 1 \\
\hline methamidophos & OP & 90 & 5 & 24 & $4(2-6)$ \\
\hline mevinphos & OP & 27 & 17 & 21 & $1(1-12)$ \\
\hline monocrotophos & OP & 26 & 134 & - & $30(1-35)$ \\
\hline omethoate & OP & Stable & 17 & 5 & 14 \\
\hline oxydemeton-methyl & OP & 222 & $73(96-41)$ & 3 & 5 \\
\hline phorate & OP & 1 & 3 & - & $63(14-90)$ \\
\hline
\end{tabular}




\begin{tabular}{llllll}
\hline Chemical & Group & Water & & Field & \\
\hline phosphamidon & OP & - & $36(60-12)$ & 13 & $12(9-17)$ \\
\hline thiometon & OP & - & 22 & - & $2(2-7)$ \\
\hline vamidothion & OP & - & $\mathbf{1 1 9}$ & 7 & $1(<1-2)$ \\
\hline fipronil & PP & 0.33 & stable & 68 & $65(6-135)$
\end{tabular}

Table 2. Degradation of systemic insecticides expressed as half-lives in days. Compounds with half-lives longer than 100 days are considered persistent (Sources: Footprint database \& [284]. a for pH 9C = carbamates; $D=$ dithiol; IGR = Insect growth regulator; $\mathrm{N}=$ neonicotinoid; $\mathrm{OP}=$ organophosphate; $\mathrm{PP}=$ phenylpyrazole

Aquatic organisms take up easily whatever residues reach the waterbodies, through runoff from treated fields or contaminated groundwater. Some $20 \%$ systemic insecticides are prone to leaching, and $45 \%$ are mobile in wet soils (Table 1). For example, acephate leaches more easily than methamidophos [305], and so acephate should be restricted or avoided in tropical areas and rice crops [46]. Residues of aldicarb and methomyl in groundwater can have sublethal effects in mammals [215]. Even if residue levels of systemic insecticides in rivers and lakes are usually at ppb levels $(\mu \mathrm{g} / \mathrm{L})$, persistent compounds such as fipronil, neonicotinoids and growth regulators can have chronic effects due to their constant presence throughout several months in the agricultural season [123]. For example, about 1-2\% of imidacloprid in treated soil moves into runoff after rainfall events, with the highest concentrations recorded at $0.49 \mathrm{mg} / \mathrm{L}$ [12]. Systemic carbamates and OPs do not last long in water because they breakdown through photolysis or hydrolysis in a few days, or are taken up and degraded by aquatic plants [100]. In any case, their presence and frequency of detection in water depends on local usage patterns $[39,171]$. The acute toxicity of most systemic compounds is enhanced in aquatic insects and shrimp under saline stress [22, 253].

A characteristic feature of most systemic insecticides -except carbamates- is their increased toxicity with exposure time, which results from a constant or chronic uptake through either feeding or aquatic exposure (Figure 1). Effects are more pronounced some time after the initial application [16], and could last up to eight months [286]. Also, as a result of chronic intoxication, there may not be limiting toxic concentrations (e.g. NOEC or NOEL) in compounds that have irreversible mechanism of toxicity, since any concentration will produce an effect as long as there is sufficient exposure during the life of the organism [274]. This is precisely their main advantage for pest control: any concentration of imidacloprid in the range $0.2-1.6 \mathrm{ml} / \mathrm{L}$ can reduce the population of mango hoppers (Idioscopus spp.) to zero within three weeks [291]. However, it is also the greatest danger for all non-target species affected, e.g. predators, pollinators and parasitoids. By contrast, contact insecticides act usually in single exposures (e.g. spray droplets, pulse contamination after spraying, etc.) and have the highest effects immediately after application. 


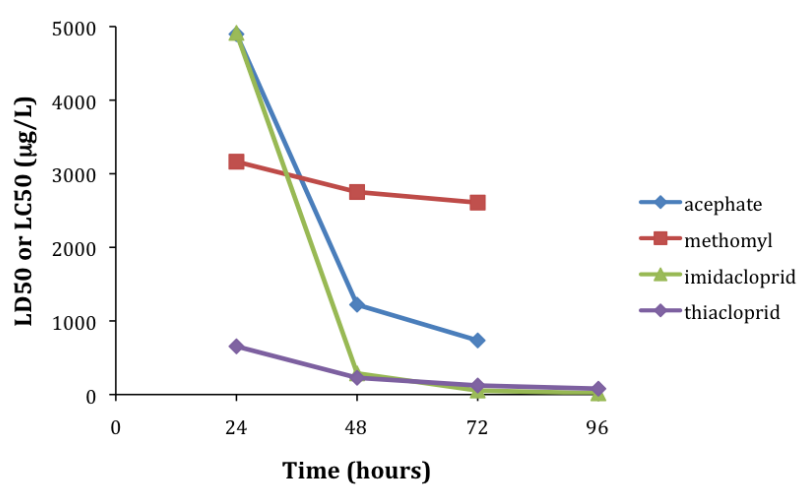

Figure 1. Increasing toxicity of several systemic insecticides with time of exposure. LD50 for acephate to Episyrphus bateatus and for methomyl to Bombus terrestris [75]; LC50 for imidacloprid to Cypridopsis vidua [234] and thiacloprid to Sympetrum striolatum [28].

\section{Modes of action of systemic insecticides}

Before describing their impacts on organisms and ecosystems, a description of the mechanisms of toxicity of systemic insecticides is briefly outlined.

\subsection{Acetylcholinesterase inhibitors}

Carbamates and organophosphorus compounds are inhibitors of the acetylcholinesterase enzyme (AChE), thus blocking the transmission of the nervous impulse through the neuronal synapses. The binding of carbamates to the enzyme is slowly reversible and temporary, i.e. < 24 h [197], whereas that of alkyl OPs is irreversible. The binding of methyl-OPs does not last as long as that of alkyl-OPs, and this feature is compound specific [182]. Given their mode of action, all these compounds are broad-spectrum insecticides, extremely toxic to most animal taxa, from worms to mammalian vertebrates. Avian species are often more susceptible to these compounds due to relatively low levels of detoxifying enzymes in birds $[207,297]$. Thus, recovery of ducklings exposed to a range of carbamate and OP insecticides occurred within eight days after being depressed 25-58\% following dosing [91].

\subsection{Insecticides acting on nicotinic acetylcholine receptors (nAChR)}

Neonicotinoids are derived from nicotine, which is found in the nightshade family of plants (Solanaceae), and particularly in tobacco (Nicotiana tabacum). They all are agonists of the nicotinic acetylcholinesterase receptor (nAChR), which mediate fast cholinergic synaptic transmission and play roles in many sensory and cognitive processes in invertebrates. Binding of neonicotinoids to these receptors is irreversible in arthropods [40, 307]. Given that nAChRs are embedded in the membrane at the neuronal synapses, their regeneration seems unlikely 
because neurons do not grow. The lower affinity of neonicotinoids for mammalian nAChRs has been attributed to the different ionic structure of the vertebrate subtypes [283]. The high toxicity of neonicotinoids to insects and worms is comparable to that of pyrethroids, but aquatic crustaceans, particularly waterfleas, are more tolerant $[119,136]$.

Cartap is a dithiol pro-insecticide that converts to nereistoxin, a natural toxin found in marine Nereis molluscs. Both cartap and nereistoxin are antagonists of the $\mathrm{nAChR}$ in insects and other arthropods [164], blocking irreversibly the neuronal functions of these receptors. Unlike neonicotinoids, cartap appears to be very toxic to fish and amphibians [235].

\subsection{GABA-R antagonists (fipronil)}

Fipronil is a phenylpyrazole antagonist of the $\gamma$-aminobutyric acid (GABA)-gated chloride channel, binding irreversibly to this receptor and impeding the nervous transmission [56]. Its mode of action, therefore, appears to be identical to that of cyclodiene organochlorins (e.g. endosulfan), but fipronil is mostly systemic whereas all cyclodienes are insecticides with contact activity. Interestingly, while aquatic organisms (e.g. cladocerans, fish) are quite tolerant of fipronil, vertebrates are more susceptible to this compound than to the old organochlorins [235].

\subsection{Insect growth regulators (IGR)}

Hexaflumuron, novaluron and teflubenzuron are the only systemic benzoylureas in the market. They are chitin inhibitors, blocking the biosynthesis of this essential component of the arthropod's exoskeleton. As a consequence, insects and other arthropods cannot moult and die during their development. Since their mode of action is restricted to arthropods, benzoylureas are not very toxic to any other animal taxa, e.g. molluscs, vertebrates, etc. [235].

Halofenozide is the only systemic compound among the hydrazines, a group of chemicals that mimic the steroidal hormone ecdysone, which promotes moulting in arthropods [71]. The premature moulting in larvae of some insect taxa, particularly in Lepidoptera, prevents them from reaching the adult stage. Toxicity of halofenozide is selective to insects only.

\section{Effects on organisms and ecosystems}

\subsection{Direct effects on organisms}

Mortality of non-target organisms exposed to insecticides is mostly due to acute toxicity, particularly in the case of carbamates. However, with systemic compounds there are many observations of long-term suppression of populations that suggest a chronic lethal impact over time. The latter impacts are likely due to persistence of residual activity in the soil, foliage or water in the case of reversible toxicants (i.e. carbamates), or to irreversible and persistent binding in other cases. (note: all application rates and concentrations here refer to the active ingredient). 


\subsubsection{Acetylcholinesterase inhibitors}

These compounds can have serious impacts on soil organisms of various taxa. Aldicarb and phorate applied to a cotton crop soil at 0.5 and $1 \mathrm{~kg} / \mathrm{ha}$, respectively, eliminated or reduced significantly non-target mesofauna, including mites and springtails. Populations of the latter taxa were reduced for more than 60 days (phorate) and 114 days (aldicarb) [17, 225], with the highest effects peaking after 18 days [16]. Granular applications of phorate $(250 \mathrm{mg} / \mathrm{kg}$ dry soil) killed almost all earthworms, Collembola, Acarina, free-living saprophytic and parasitic nematodes and Protozoa, with populations of Collembola recovering only when residues went below $2 \mathrm{mg} / \mathrm{kg}$ [300]. After a single aldicarb application to soil at $2.5 \mathrm{~g} / \mathrm{m}^{2}$, Gamasina predatory mites went to extinction within a year [148]. Bendiocarb impacts on predaceous arthropods and oribatid mites were less severe and temporary compared to the impacts of non-systemic OPs, but increased trap catches of ants two weeks after application [55], possibly as a result of a longer-term effect. Many soil arthropods, in particular mites and springtails, were the most affected by dimethoate -and its metabolite omethoate- residues in soil after sprays of $1-2 \mathrm{ml} / \mathrm{L}$ in the farms of the Zendan valley, Yemen [4]. Similar observations were made when dimethoate was sprayed on vegetation of arable fields [85] or in soil microcosms [180]; the springtail populations recovered but attained lower densities a year later, while their dominance structure had changed. However, dimethoate or phosphamidon applied in mustard fields produced only a temporary decline, compared to the longlasting effect of monocrotophos [141]. Collembola populations do not seem to be affected by pirimicarb applications on cereal crops [95].

Earthworm populations were affected initially after application of phorate and carbofuran to turfgrass, but not thiofanox, and their numbers recovered subsequently [53]. Reduction of earthworm populations by bendiocarb was the highest (99\% in one week) among 17 insecticides applied at label rates on turfgrass, with significant effects lasting up to 20 weeks [216]. Juveniles and species living in the surface layers or coming to the soil surface to feed (e.g., Lumbricus terrestris) are most affected, since a high degree of exposure is usually found in the first $2.5 \mathrm{~cm}$ of soil [288]. However, systemic carbamates can be selective to plant-parasitic nematodes without affecting fungal or microbial communities [296]. Thus, cholinesterase inhibitors do not have significant impacts on bacteria, fungi and protozoa in soil [133], and consequently do not alter the soil biochemical processes [79]. Nevertheless, a combined dimethoate-carbofuran application reduced active hyphal lengths and the number of active bacteria in a treated forest soil [58].

Populations of beneficial predators can be decimated initially as much as the target pests, but they usually recover quickly. For example, thiodicarb or its degradation product, methomyl, applied at $0.5 \mathrm{~kg} / \mathrm{ha}$ on soybean crops, significantly reduced populations of the predatory bugs Tropiconabis capsiformis and Nabis roseipennis within two days after treatment only [25]. Demeton-S-methyl reduced populations of predatory insects on strawberry patches, whereas pirimicarb and heptenophos had no significant effect on spiders, staphylinids and anthocorids, or on hymenopteran parasitoids [76]. While populations of web spiders and carabid beetles are severely reduced by dimethoate applied to cabbage fields and cereal crops [144], pirimicarb does not seem to have much impact on these taxa [97, 195], affecting 
mainly aphids [131]. Pirimicarb on wheat crops does not impact on ladybirds, but larvae of Episyrphus balteatus are affected [135]. By contrast, longer impacts have been observed with acephate applied at $0.5 \mathrm{~kg} / \mathrm{ha}$ on rice paddies, which reduced populations of predatory bugs (Cyrtorrhinus lividipennis and Paederus fuscipes) for at least 10 days [155]. Similar rates of acephate on rice and soybean crops reduced spiders populations for three weeks, but they recovered afterwards [181]. In addition, acephate is deadly to three species of whitefly parasitoid species [267].

Direct mortality of bumble bees (Bombus terrestris) in short exposures to dimethoate is much higher than for heptenophos or ethiofencarb [132]. However, what matters most is the chronic toxicity to the entire bee colony not just the workers. For example, methamidophos contaminated syrup ( $2 \mathrm{mg} / \mathrm{L})$ produced significant losses of eggs and larvae of honey bees without any appreciable loss of workers after one week of exposure; the colonies would recover completely within 13 weeks if the insecticide was applied only once [301], indicating a long-term impact on the colony. Similarly, the mortality of non-target adult chrysomelid beetles (Gastrophysa polygoni) after foliar treatment with dimethoate on the host plants was low (1.9-7.6\%), but because this insecticide was most toxic to the egg stage, the overall beetle population decreased over time due to hatching failure [146].

Primary poisoning of birds and mammals by ingestion of OP and carbamate granules or coated seeds is still a problem despite the many attempts to reduce these impacts $[189,190]$. For example, mortality of birds that ingested granules of carbofuran in a corn field was extensive, affecting waterfowl, small songbirds and mice within 24 hours. Residues up to 17 $\mathrm{mg} / \mathrm{kg}$ body weight (b.w.) were found in the dead animals [19]. The granular formulation of this carbamate was banned in the mid-1990s by the US EPA after numerous cases of direct poisoning by animals; however, the liquid formulation applied to alfalfa and corn is just as deadly to bees, because this systemic insecticide is present in the pollen of those plants [208]. Phosphamidon sprayed at $1 \mathrm{~kg} / \mathrm{ha}$ to larch forests in Switzerland caused many bird deaths [243]; large bird mortality was also observed in Canadian spruce forests sprayed with phosphamidon $(0.55 \mathrm{~kg} / \mathrm{ha})$, particularly among insectivorous warblers. There was good evidence that birds picked up the insecticide from sprayed foliage within a few hours of application [94]. Carbofuran and phosphamidon were the most common pesticides implicated in deaths of wild birds in Korea between 1998-2002 [157], and ducklings died in large numbers when phorate was applied to South Dakota wetlands [73]. Usually birds die when their brain AChE depression is over 75\% [92, 114]. Thus, 11 out of 15 blue jays (Cyanocitta cristata) which had depression levels ranging 32-72\% after disulfoton was sprayed to pecan groves would die [302], but their carcasses would probably not be found. In orchards sprayed with methomyl, oxamyl or dimethoate, the daily survival rates for nests of Pennsylvania mourning dove (Zenaida macroura) and American robin (Turdus migratorius) were significantly lower than in non-treated orchards, and the species diversity was also lower. Repeated applications of these and other insecticides reduced the reproductive success of doves and robins and may have lowered avian species diversity [93].

Secondary poisoning with bendiocarb was attributed to 22 birds that had depressed AChE activity after eating contaminated mole crickets and other soil organisms on the applied 
turfgrass [224]. Several species of raptors were killed or debilitated after consuming waterfowl contaminated with phorate - the fowl had ingested granules of the insecticide that were applied to potato fields a few months earlier [84]. Equally, ladybugs (Hippodamia undecimnotata) fed upon Aphis fabae, which were reared on bean plants treated with carbofuran, experienced a $67 \%$ population reduction due to secondary poisoning [206]. Pirimicarb caused $30-40 \%$ mortality of Tasmanian brown lacewing (Micromus tasmaniae) larvae when feeding on contaminated 1st instar lettuce aphid (Nasonovia ribisnigri) for three days [298].

Impacts on aquatic organisms usually do not last more than a month. For example, thiodicarb applied at $0.25-1.0 \mathrm{~kg} / \mathrm{ha}$ had severe impacts on copepods, mayflies and chironomids in experimental ponds for three weeks, but not so much on aquatic beetle's larvae; eventually there was recovery of all populations [7]. Pirimicarb can be lethal to common frog (Rana temporaria) tadpoles, but does not appear to have chronic effects [139]. However, vamidothion and acephate are most lethal to non-target organisms in rice crops, and are not recommended in IPM programs [153]. Carbofuran and phorate are very toxic to aquatic invertebrates [140], particularly amphipods and chironomids but not so much to snails, leeches or ostracods [72, 249]. Small negative effects in zooplankton communities (cladocerans copepods and rotifers) were observed in rice paddies treated with carbofuran at recommended application rates, but fish were not affected [107]. Carbofuran should not be used in rice paddies, whether in foliar or granular formulations: not only induces resurgence of the brown planthoppers (Nilaparvata lugens) [122], but it is also more toxic to the freshwater flagellate Euglena gracilis than the non-systemic malation [15]. It reduces populations of coccinellid beetles, carabid beetles, dragonfly and damselfly nymphs, but does not impact much on spiders [255]. However, it appears that carbofuran at $0.2 \%$ per ha can double the densities of Stenocypris major ostracods in rice paddies, whereas other insecticides had negative effects on this species [168]. Repeated applications of carbofuran can also have a significant stimulation of the rhizosphere associated nitrogenase activity, with populations of nitrogen-fixing Azospirillum sp., Azotobacter sp. and anaerobic nitrogen-fixing bacteria increasing progressively up to the third application of this insecticide [142].

\subsubsection{Insecticides acting on $n A C h R$}

Direct toxicity of cartap to fish species is not as high as that of other neurotoxic insecticides, with 3-h LC50s between 0.02 and $6.8 \mathrm{mg} / \mathrm{L}$ [161, 308]. However, cartap affects negatively several species of Hymenoptera and aphid parasitoids used to control a number of crop pests [14, 77, 147, 270]. This insecticide also inhibits hatching of eggs of the nematode Agamermis unka, a parasite of the rice pest Nilaparvata lugens [50], and reduces significantly the populations of ladybugs and other predatory insects in cotton crops when applied at the recommended rates, i.e. $20 \mathrm{~g} / \mathrm{ha}[109,169]$. In rice paddies, cartap hydrochloride reduced populations of coccinellid beetles, carabid beetles, dragonflies and damselflies by 20-50\% [255]. Pollinators such as honey bees and bumble bees can also be seriously reduced in numbers when feeding on crops treated with cartap hydrochloride, which is included among the most toxic insecticides to bees after neonicotinoids and pyrethroids [179, 278]. For all its negative impacts on parasitoids and predatory insects it is hard to understand why cartap was 
the third most common insecticide (19\% of all applications) used in IPM programs in Vietnam a decade ago [31], and is still among the most widely used in rice farms in China [308].

Cumulative toxicity of neonicotinoids over time of exposure results in long-term pest control compared to the impact of cholinesterase inhibitor insecticides. For example, soil treated with clothianidin at $0.05-0.15 \%$ caused increasing mortality in several species of wireworms (Coleoptera: Elateridae), reaching $30-65 \%$ after 70 days, whereas chlorpyrifos at $0.15 \%$ produced 35\% mortality within 30 days but no more afterwards [292]. Soil application of imidacloprid did not eliminate rapidly Asian citrus psyllid (Diaphorina citri) and leafminer (Phyllocnistis citrella) populations, but resulted in chronic residues in leaf tissue and longterm suppression of both pests [245]. Also, soil applications of neonicotinoids are very effective in controlling soil grubs and berry moths (Paralobesia viteana) in vineyards provided there is no irrigation or rain that washes off the insecticide [289]. For the same reason, however, the impact of neonicotinoids on non-target organisms is long-lasting. For example, repeated corn-seed treatement with imidacloprid caused a significant reduction in species richness of rove beetles in three years, even though the abundance of the main species was not affected [88]. In addition to long-term toxicity, acute toxicity of acetamiprid, imidacloprid and thiomethoxam to planthopper and aphid species is similar to that of synthetic pyrethroids, and higher than that of endosulfan or acetylcholinesterease inhibitors [219, 246]. Thus, combinations of pyrethroid-neonicotinoid have been hailed as the panacea for most pest problems as it suppresses all insect resistance [70]. Mixtures of imidacloprid and thiacloprid had additive effects on the toxicity to the nematode Caenorhabditis elegans but not on the earthworm Eisenia fetida [108].

Acute toxicity of imidacloprid, thiamethoxam, clothianidin, dinotefuran and nitenpyram to honey bees is higher than that of pyrethroids, while toxicity of acetamiprid and thiacloprid is increased by synergism with ergosterol-inhibiting fungicides [134, 242] and antibiotics [116]. Thus, neonicotinoids can pose a high risk to honey bees, bumble bees [176, 263] and wasps [90]. Bees can be killed immediately by direct contact with neonicotinoid droplets ejected from seed drilling machines. Thus, numerous worker bees were killed when seed was coated with clothianidin during drilling of corn in the Upper Rhine Valley (Germany) in spring 2008 [102]. The same problem happened in Italy with thiamethoxam, imidacloprid and clothianidin $[105,285]$, leading to the banning of this application method on sunflower, canola and corn during 2008-09 [20]. However, most of the time bee colonies are intoxicated by feeding on contaminated pollen and nectar $[9,228]$. It has been observed that bee foraging was notably reduced when Indian mustard was treated with $178 \mathrm{mg} / \mathrm{ha}$ imidacloprid [10]. Imidacloprid residues in sunflowers are below the no-adverse-effect concentration to honey bees of $20 \mu \mathrm{g} / \mathrm{kg}$ at 48-h [241], with surveys in France showing residue levels in pollen from treated crops in the range $0.1-10 \mu \mathrm{g} / \mathrm{kg}$ and average in nectar of $1.9 \mu \mathrm{g} / \mathrm{kg}$ [33]. However, bees feeding on such contaminated pollen or nectar will reach first sublethal and later lethal levels, with 50\% mortality occurring within 1-2 weeks [228, 266]. Such data was disputed $[89,240]$ as it was in conflict with some long-term field observations of honey bees feeding on sunflowers grown from imidacloprid-treated seeds at $0.24 \mathrm{mg} / \mathrm{seed} \mathrm{[256].} \mathrm{How-}$ ever, recent evidence suggest that chronic lethality by imidacloprid is implicated in the colo- 
ny collapse disorder (CCD) that affects honey bees [174]. Based on the fast degradation of imidacloprid in bees (4-5 hours), it is assumed that honey bees which consume higher amounts of imidacloprid die already outside of the hive, before the colony's demise and before samples are taken, though residues of imidacloprid in bees at $5-8 \mu \mathrm{g} / \mathrm{kg}$ have been found in some cases [111]. Clothianidin residues of $6 \mu \mathrm{g} / \mathrm{kg}$ in pollen from canola fields reduced the number of bumble bee (Bombus impatients) workers slightly ( 20\%) [96], but exposure to clothianidin-treated canola for three weeks appeared not to have affected honey bee colonies in Canada [61]. Thiamethoxam applied to tomatoes ( 150 g/ha) through irrigation water does not have impacts on bumble bees (Bombus terrestris) [244], whereas pollen contaminated with this insecticide causes high mortality and homing failure [125].

Negative impacts of neonicotinoids on non-target soil arthropods are well documented. A single imidacloprid application to soil reduced the abundance of soil mesofauna as well as predation on eggs of Japanese beetle (Popillia japonica) by 28-76\%, with impacts lasting four weeks. The same level of impact was observed with single applications of clothianidin, dinotefuran and thiamethoxam, so the intended pest control at the time of beetle oviposition runs into conflict with unintended effects - disruption of egg predation by non-target predators [210]. Among several insecticides applied to home lawns, only imidacloprid suppressed the abundance of Collembola, Thysanoptera and Coleoptera adults, non-oribatid mites, Hymenoptera, Hemiptera, Coleoptera larvae or Diptera taxonomic groups by $54-62 \%$ [209]. Imidacloprid applied to the root of eggplants $(10 \mathrm{mg} / \mathrm{plant})$ greatly reduced most arthropod communities and the species diversity during the first month. Small amounts of soil residues that moved into the surrounding pasture affected also some species; however, non-target ground arthropods both inside and outside the crop showed significant impacts only in the two weeks after planting [238], probably due to compensatory immigration from nearby grounds.

Foliar applications of thiamethoxam and imidacloprid on soybean crops are preferred to seed treatments, as neonicotinoids appear to have lesser impacts on non-target communities than pyrethroids [204]. However, a foliar application of thiacloprid $(0.2 \mathrm{~kg} / \mathrm{ha})$ to apple trees reduced the population of earwigs (Forficula auricularia), an important predator of psyllids and woolly apple aphid, by $60 \%$ in two weeks, while remaining below $50 \%$ after six weeks [294]. Branchlets of hemlock (Tsuga canadensis) treated with systemic imidacloprid (1-100 $\mathrm{mg} / \mathrm{kg}$ ) reduced the populations of two non-target predators of the hemlock woolly adelgid (Adelges tsugae) and had both lethal and sublethal effects on them [78]. Clothianidin, thiamethoxam and acetamiprid were as damaging to cotton crop predators as other broad-spectrum insecticides and cartap [169]. All neonicotinoids are lethal to the predatory mirid Pilophorus typicus, a biological control agent against the whitefly Bemisia tabaci, since their residual activity can last for 35 days on the treated plants [201]. The ladybug Serangium japonicum, also a predator of the whitefly, is killed in large numbers when exposed to residues of imidacloprid on cotton leaves applied at the recommended rate (40 ppm) or lower; apparently, the predator was not affected when imidacloprid was applied as systemic insecticide [120]. Clothianidin is 35 times more toxic to the predatory green miridbug (Cyrtorhinus lividipennis 48 -h LC50 $=6 \mu \mathrm{g} / \mathrm{L}$ ) than to the main pest of rice (Nilaparvata lugens $48-\mathrm{h}$ LC50 = 211 $\mu \mathrm{g} / \mathrm{L}$ ), thus questioning seriously its application in such crops [221]. Not surprisingly, popu- 
lations of predatory miridbugs and spiders suffered an initial set back when rice paddies were treated with a mixture of ethiprole+imidacloprid $(125 \mathrm{~g} / \mathrm{ha})$, and their recovery was slow and never attained the densities of the control plots [154]. Mixtures of ethiprole+imidacloprid and thiamethoxam $+1 \lambda$-cyhalothrin on rice paddies are also highly toxic to mirid and veliid natural enemies of rice pests, with $100 \%$ mortalities recorded in $24 \mathrm{~h}$ [159].

Secondary poisoning with neonicotinoids reduces or eliminates eventually all predatory ladybirds in the treated areas, compromising biological control in IPM programs. Indeed, exposure of larval stages of Adalia bipunctata to imidacloprid, thiamethoxam, and acetamiprid, and adult stages to imidacloprid and thiamethoxam, significantly reduced all the demographic parameters in comparison with a control -except for the mean generation time-, thus resulting in a reduced coccinellid population; adult exposures produced a significant population delay [162]. Eighty percent of 3rd and 4th instar larvae of the ladybug Harmonia axyridis died after feeding for 6 hours on corn seedlings grown from seeds treated with clothianidin, compared to $53 \%$ mortality caused by a similar treatment with thiamethoxam; recovery occurred only in $7 \%$ of cases [196]. Survival of the ladybird Coleomegilla maculata among flower plants treated with imidacloprid at the label rate was reduced by $62 \%$ [251], and Hippodamia undecimnotata fed upon aphids reared on bean plants treated with imidacloprid, experienced a $52 \%$ population reduction [206]. Equally, 96\% of Tasmanian brown lacewing (Micromus tasmaniae) larvae died after feeding on 1st instar lettuce aphid (Nasonovia ribisnigri) for three days. Low doses did not increase mortality but from days 3 to 8, lacewing larvae showed significant evidence of delayed developmental rate into pupae [298]. Grafton-Cardwell and $\mathrm{Wu}$ [110] demonstrated that IGRs, neonicotinoid insecticides, and pyrethroid insecticides have a significant, negative impact on vedalia beetles (Rodolia cardinalis), which are essential to control scale pests in citrus; neonicotinoids were toxic to vedalia larvae feeding on cottony cushion scale that had ingested these insecticides, and survival of adult beetles was also affected but to a lesser extent than other insecticides.

Recent evidence of the negative impacts of neonicotinoids on parasitoids reinforces that these insecticides are not suitable for IPM [271]. All neonicotinoids are deadly to three whitefly parasitoid species (Eretmocerus spp. and Encarsia formosa), with mortality of adults usually greater than the pupae [267]. Thiamethoxam appears to be less toxic to whitefly parasitoids compared to imidacloprid [202]. Imidacloprid, thiamethoxam and nitenpyram appeared to be the most toxic to the egg parasitoids Trichogramma spp. [231, 299]. For example, the acute toxicity of thiomethoxam and imidacloprid to Trichogramma chilonis, an egg parasitoid of leaf folders widely used in cotton IPM, is about 2000 times higher than that of other insecticides used in rice crops in India, such as acephate or endosulfan [220]. Acute toxicity of imidacloprid is more pronounced on Braconidae parasitoids than on T. chilonis, whereas thiacloprid only reduced the parasitization on Microplitis mediator [192]. Thiacloprid is as toxic to the cabbage aphid Brevicoryne brassicae as to its parasitoid (Diaeretiella rapae), whereas pirimicarb and cypermethrin are more toxic to the aphid and are, therefore, preferred in IPM [3].

Neonicotinoids pose also risks to aquatic taxa. The synergistic toxicity of imidacloprid+thiacloprid on Daphnia magna [173] implies the combined effect of neonicotinoids on aquatic arthropods would be higher than expected, even if Daphnia is very tolerant of neonicoti- 
noids [119]. Other contaminants, such as the nonylphenol polyethoxylate (R-11) act also synergistically with imidacloprid [49]. Thiacloprid causes delayed lethal and sublethal effects in aquatic arthropods, which can be observed after 4 to $12 \mathrm{~d}$ following exposure to single $24-\mathrm{h}$ pulses [28]. Thus, its $5 \%$ hazardous concentration $(0.72 \mu \mathrm{g} / \mathrm{L})$ is one order of magnitude lower than predicted environmental concentrations in water [35]. Also, thiacloprid LC50 for survival of midges (Chironomus riparius) is only $1.6 \mu \mathrm{g} / \mathrm{L}$, and EC50 for emergence $0.54 \mu \mathrm{g} / \mathrm{L}$ [160], so both acute and chronic toxicity reduce the survival and growth of $C$. tentans and Hyalella azteca [265]. Acute toxicity of neonicotinoids to red swamp crayfish (Procambarus clarkii) is 2-3 orders of magnitude lower than that of pyrethroids [23]; comparative data such as this gives the neonicotinoids an apparent better environmental profile. However, experimental rice mesocosms treated with imidacloprid at label rates $(15 \mathrm{~kg} / \mathrm{ha})$ eliminated all zooplankton communities for two months, and their recovery did not reach the control population levels four months later. Equally, mayflies, coleoptera larvae and dragonfly nymphs were significantly reduced while residues of imidacloprid in water were above $1 \mu \mathrm{g} / \mathrm{L}[117,237]$. Similarly, streams contaminated with a pulse of thiacloprid $(0.1-100 \mu \mathrm{g} / \mathrm{L})$ resulted in long-term $(7$ months) alteration of the overall invertebrate community structure [27]. However, while aquatic arthropods with low sensitivity to thiacloprid showed only transient effects at $100 \mu \mathrm{g} / \mathrm{L}$, the most sensitive univoltine species were affected at $0.1 \mu \mathrm{g} / \mathrm{L}$ and did not recover during one year [167].

\subsubsection{Fipronil}

Fipronil is very efficient in controlling locust outbreaks, but causes more hazards than chlorpyrifos and deltamethrin to non-target insects in the sprayed areas, although it is more selective to specific taxa [214, 252]. Thus, abundance, diversity and activity of termites and ants were all reduced in northern Australia after spraying several areas with fipronil for locust control [262], and $45 \%$ of the termite colonies died within 10 months of a spraying operation with fipronil for controlling locusts in Madagascar [214]. Reducing the recommended application rates by seven times (0.6-2 g/ha) still achieves $91 \%$ elimination of locusts while having lesser impacts on non-target organisms, comparable to those inflicted by carbamate and OP insecticides [18].

Despite its selectivity, fipronil in maize crops reduced the abundance of arthropod populations of the soil mesofauna more significantly than other systemic insecticides, i.e. carbofuran [59], although springtails are little affected as they avoid feeding on litter contaminated with fipronil and are more tolerant of this insecticide [232]. When applied to citrus orchards, fipronil was among the most detrimental insecticides affecting two Euseius spp. of predatory mites [112]. In rice crops, the effectiveness of fipronil in controlling pests was overshadowed by its negative impact on the predatory miridbugs Cyrtorhinus lividipennis and Tytthus parviceps [159].

Of greater concern is the impact of this systemic chemical on honey bees and wild bee pollinators. With an acute contact LD50 of $3.5 \mathrm{ng} / \mathrm{bee}$ [166] and acute oral LD50 of 3.7-6.0 ng/bee [2], fipronil is among the most toxic insecticides to bees ever developed. Even more worrying is the finding that the adjuvant Sylgard, used to reduce the toxicity of most insecticidal 
products on bees, increases the toxic effects of fipronil [184]. The systemic nature of this chemical implies that chronic feeding of the bees on nectar contaminated with fipronil caused $100 \%$ honey bee mortality after 7 days, even if the residue concentration was about 50 times lower than the acute lethal dose [8]. Residues of fipronil in pollen have been measured as $0.3-0.4 \mathrm{ng} / \mathrm{g}$, which are $30-40$ times higher than the concentration inducing significant mortality of bees by chronic intoxication [33]. Unlike neonicotinoids, no residues of fipronil have been found in guttation drops [272].

The acute toxicity of fipronil to cladocerans is similar to the toxicity to estuarine copepods, with 48-h LC50 in the range 3.5-15.6 $\mu \mathrm{g} / \mathrm{L}[47,259]$, but the chronic toxicity with time of exposure is what determines the fate of the populations exposed. For example, populations of Daphnia pulex went to extinction after exposure to $80 \mu \mathrm{g} / \mathrm{L}$ for 10 days, equivalent to LC75 [259], and $40 \%$ of a population of grass shrimps (Palaemonetes pugio) died in 28 days after being exposed to fipronil concentrations of $0.35 \mu \mathrm{g} / \mathrm{L}$ in marsh mesocosms, and none of the shrimps survived when exposed to $5 \mathrm{mg} / \mathrm{L}$ during the same period [303]. Such impacts on zooplankton are likely to occur in estuaries, where waters have been found to contain 0.2-16 $\mu \mathrm{g} / \mathrm{L}$ of fipronil residues [45, 163], even if no apparent effect on amphipods, mussels nor fish has been observed [37,303]. Fipronil sprays on water surfaces to control mosquito larvae have negative impacts not only on cladocerans but also on chironomid larvae exposed to chronic feeding on contaminated residues $[183,264]$. Studies on rice mesocosms have shown that significant population reductions due to fipronil application at the recommended rates (50 g per seedling box) are not restricted to zooplankton and benthic species, but affect most species of aquatic insects. Moreover, fipronil impacts on aquatic arthropods were more pronounced after a second application in the following year [118], indicating persistence of this insecticide in rice paddies. Chronic toxicity over time explains the long-term toxicity of this systemic compound, so it is not surprising that concentrations of $1.3 \mu \mathrm{g} / \mathrm{L}$ in paddy water were sufficient to kill 100\% of dragonfly (Sympetrum infuscatum) nymphs in nine days [138].

\subsubsection{Insect growth regulators}

There is little information about the effect of systemic chitin inhibitors on non-target organisms. Obviously these compounds are harmless to fish at levels above $1 \mathrm{mg} / \mathrm{L}$ for a weeklong exposures [290], and to all vertebrates in general. IGRs affect mainly the larval stages of Lepidoptera, Coleoptera and Hymenoptera, and their activity last longer than that of other pest control products [178]. The effectiveness of these compounds in controlling target pests is demonstrated by comparing the dietary LC50 of hexaflumuron $(0.31 \mathrm{mg} / \mathrm{L})$ to the target cotton worm (Helicoverpa sp.), which is 35 times lower than that of the systemic carbamate thiodicarb and less damaging to non-target predators [64]. Aquatic communities of non-target arthropods in rice fields (e.g. Cladocera, Copepoda, Odonata, Notonectidae, Coleoptera and Chironomidae taxa) were not affected by teflubenzuron applied at rates to control mosquitoes $(5.6 \mathrm{mg} / \mathrm{ha})$, even though this IGR remained active for several weeks during autumn and winter periods [239].

After application of IGRs to a crop, affected insect pests are prey to many species of spiders, some of which are also susceptible to the toxicity of these products, in particular the ground 
hunter spiders [211]. Larvae and eggs of pests contaminated with systemic IGR are consumed by a number of predators, including earwigs, which undergo secondary poisoning and stop growing beyond the nymph stage [226]. Chitin inhibitors only show effects on the larvae of predatory insects that had consumed treated-prey, not on the adult insects. As a consequence, predatory populations collapse, as it happened with the ladybeetle Chilocorus nigritus that fed on citrus red scales (Aonidiella aurantii) in African orchards that had been treated with teflubenzuron [177]. Teflubenzuron sprayed at $16.4 \mathrm{~g} / \mathrm{ha}$ for locust control in Mali did not affect the non-target arthropods in the herb layer, whereas ground-living Collembola, Thysanura, Coleoptera and Lepidoptera larvae were reduced by about 50\% [151]. Moreover, teflubenzuron has multigenerational impacts: experiments with springtails exposed to artificial soil contaminated with this IGR showed that the F2 generation suffered significantly from its effects even when only the F0 generation had been exposed for 10 days [42]. Secondary poisoning with chitin inhibitors can be detrimental also to parasitoids such as Diadegma semiclausum, which may fail to produce enough cocoons in the treated hosts, but do not seem to affect the parasitism of other Hymenoptera [98]. For instance, novaluron did not affect the parasitisation of Trichogramma pretiosum on mill moth's caterpillars, a pest of tomato crops [44]. On the other hand, teflubenzuron appears to be harmless to predatory mites [32]. IPM programs must always consider the implications of using systemic chitin inhibitors to control specific pests without destroying their natural predators in the first place.

Halofenozide does not appear to cause any acute, adverse effects through topical, residual, or dietary exposure of the ground beetle Harpalus pennsylvanicus. In contrast to the negative effects of other systemic insecticides (i.e. imidacloprid), the viability of eggs laid by females fed halofenozide-treated food once, or continuously for 30 days, was not reduced [156].

\subsection{Sublethal effects}

Very often, sublethal effects of systemic insecticides are a first step towards mortality, as they are caused by the same neurotoxic mechanisms. Apart from these, there may be other effects on reproduction, growth, longevity, etc. when organisms are exposed to low, sublethal doses or concentrations. These effects are only observable in individuals that survive the initial exposure, or in species that are tolerant to insecticides. For a review see [69].

\subsubsection{Acetylcholinesterase inhibitors}

Longevity of the parasitoid Microplitis croceipes that fed on nectar from cotton treated with aldicarb was affected for at least 10 days after application, and its foraging ability of the parasitoid's host was severely impaired for 18 days [257]. Carbofuran caused a significant reduction of adult weight and longevity of the predator ladybug Hippodamia undecimnotata, as well as a $55 \%$ reduction in fecundity when fed on aphids contaminated with this insecticide [206]. Longevity and survival of Aphidius ervi, an important parasitoid of the pea aphid (Acyrthosiphon pisum), were significantly reduced after treating with LC25 concentrations of dimethoate or pirimicarb [11]. A significant reduction in body size of females of the predator carabid Pterostichus melas italicus and altered sexual dimorphism were observed after longterm exposure in olives groves treated with dimethoate at a rate that caused $10 \%$ mortality 
after three days [104]. Unlike other insecticides, no behavioural effects of dimethoate or triazamate on honey bees were recorded [67].

Earthworms (Lumbricus terrestris) experienced significant reduction in growth rate and total protein content after soil applications of aldicarb at LC10 or LC25, but only small amounts of residues were detected in the worms [198]. Aldicarb and phorate can also increase infections by Rhizoctonia stem canker in potato fields [280].

A typical pattern of sublethal intoxication was revealed when red-winged blackbirds (Agelaius phoeniceus) were exposed to increasing doses of dimethoate: $2 \mathrm{mg} / \mathrm{kg} \mathrm{b.w.} \mathrm{doses} \mathrm{pro-}$ duced ataraxia, defecation and diarrhoea; neuromuscular dysfunctions and breathing complications appeared at $3 \mathrm{mg} / \mathrm{kg}$, and by $5 \mathrm{mg} / \mathrm{kg}$ muscle paralysis and death occurred. The estimated LC50 was $9.9 \mathrm{mg} / \mathrm{kg}$, and all birds died at doses above $28 \mathrm{mg} / \mathrm{kg}$ [38]. Although sublethal AChE depression by acephate (25\% brain) did not affect the attack behaviour in American kestrels (Falco sparverius) [229], nor did alter breeding behaviour in American robins (Turdus migratorius) [65], exposure to $256 \mathrm{mg} / \mathrm{kg}$ b.w. acephate impaired the migratory orientation of the white-throated sparrow (Zonotrichia albicollis) [295]. Similarly, low doses of demeton-S-methyl did not affect starlings (Sturnus vulgaris) behaviour [279], but doses of $2.5 \mathrm{mg} / \mathrm{kg}$ b.w. of dicrotophos administered to female starlings significantly reduced their parental care and feeding of nestlings [113]. Carbofuran orally administered to pigeons (Columba livia) had profound effects on flight time, with pigeons falling off the pace of the flock when doses were between 0.5 and $1.0 \mathrm{mg} / \mathrm{kg} \mathrm{b.w.} \mathrm{[36].}$

AChE activities in adductor muscle were depressed in freshwater mussels (Elliptio complanata) exposed for $96 \mathrm{~h}$ at concentrations as low as $0.1 \mathrm{mg} / \mathrm{L}$ and $1.3 \mathrm{mg} / \mathrm{L}$ of aldicarb and acephate respectively, while increasing the water temperature from 21 to $30{ }^{\circ} \mathrm{C}$ resulted in mortality [199]. High AChE inhibition (70\%) by acephate was not associated with immobility of Daphnia magna, but increasing the concentration of acephate further had a strong detrimental effect on mobility, suggesting that binding sites other than AChE may be involved in acephate toxicity [222].

Exposure of bluegill fish (Lepomis macrochirus) to $30 \mu \mathrm{g} / \mathrm{L}$ carbofuran decreased significantly adenylate parameters in gill, liver, muscle and stomach tissues after 10 days, and then returned to normal [128]. Also, concentrations of carbofuran at half the LC50 dose for fathead minnow (Pimephales promelas) larvae caused reductions in swimming capacity, increased sensitivity to electric shocks, and a reduction in upper lethal temperature [121]. Enzymes of protein and carbohydrate metabolism were altered (some increased, others decreased) in liver and muscle tissues of the freshwater fish, Clarias batrachus when exposed to $7.7 \mathrm{mg} / \mathrm{L}$ of carbofuran for six days, recovering later to normal levels [26]. Exposure of guppies (Brachydanio rerio) to half the recommended dose for dimethoate $(0.025 \mu \mathrm{l} / \mathrm{L})$ caused morphological changes in hepatocytes within three days, as well as necrosis and other abnormalities [227]. When exposed to a range of monocrotophos concentrations $(0.01-1.0 \mathrm{mg} / \mathrm{L})$, male goldfish (Carassius auratus) showed higher levels of $17-\beta$-estradiol and vitollogenin and lower levels of testosterone than normal, interfering with gonadotropin synthesis at the pituitary gland [281]. Eggs of the toad Bufo melanostictus exposed to acephate hatched normally, but the tadpoles exhibited deformities such as tail distortions and crooked trunk; decreased pigmenta- 
tion, peeling of the skin, inactivity, delay in emergence of limbs and completion of metamorphosis were also apparent [103].

Insecticide mixtures can enhance not only the acute but also the sublethal effects. For example, disulfoton together with endosulfan caused cytological and biochemical changes in liver of rainbow trout (Oncorrhynchus mykiss), independently of their respective modes of action [13]. Mixtures of aldicarb and other insecticides enhanced significantly the establishment of parasitic lungworm nematodes (Rhandias ranae) in leopard frogs (Rana pipiens) some 21 days after infection [101], as the frog's immune response was suppressed or altered [51]. Similarly, laboratory rats exposed to sublethal mixtures of aldicarb, methomyl and a herbicide (metribuzin) showed learning impairment, immune response and endocrine changes [215].

\subsubsection{Insecticides acting on $n A C h R$}

Laboratory experiments have shown a number of abnormalities such as less melanin pigmentation, wavy notochord, crooked trunk, fuzzy somites, neurogenesis defects and vasculature defects in zebrafish (Danio rerio) embryos exposed to a range of cartap concentrations. The most sensitive organ was the notochord, which displayed defects at concentrations as low as $25 \mu \mathrm{g} / \mathrm{L}$ [308]. It is obvious that essential enzymatic processes are disturbed during embryo development, among which the inhibition of lysyl oxidase is responsible for the notochord undulations observed.

Imidacloprid does not cause high mortality among eggs or adults of the preparasite nematode Agamermis unka, but impairs the ability of the nematode to infect nymphs of the host brown planthopper (Nilaparvata lugens) [50]. Contrary to this, a synergistic effect of imidacloprid on reproduction of entomopathogenic nematodes against scarab grubs may increase the likelihood of infection by subsequent generations of nematodes, thereby improving their field persistence and biological potential to control grubs. Acetamiprid and thiamethoxam, however, do not show synergist interactions with nematodes [149]. Imidacloprid at 0.1-0.5 $\mathrm{mg} / \mathrm{kg}$ dry soil disturbs the burrowing ability of Allolobophora spp. earthworms [43], and the highest concentration can also induce sperm deformities in the earthworm Eisenia fetida [306]. Reduction in body mass (7-39\%) and cast production (42-97\%) in Allolobophora spp. and Lumbricus terrestris have also been observed after 7 days exposure to relevant environmental concentrations of imidacloprid [74]. Residues of imidacloprid in maple leaves from treated forests $(3-11 \mathrm{mg} / \mathrm{kg}$ ) did not affect survival of aquatic leaf-shredding insects or litterdwelling earthworms. However, feeding rates by aquatic insects and earthworms were reduced, leaf decomposition (mass loss) was decreased, measurable weight losses occurred among earthworms, and aquatic and terrestrial microbial decomposition activity was significantly inhibited, thus reducing the natural decomposition processes in aquatic and terrestrial environments [150].

The dispersal ability of the seven-spotted ladybirds (Coccinella septempunctata) sprayed with imidacloprid was compromised, and this may have critical consequences for biological control in IPM schemes [21]. A significant reduction of adult weight and longevity of the ladybug Hippodamia undecimnotata, as well as 33\% reduction in fecundity were observed when this predatory bug fed on aphids contaminated with imidacloprid [206]. Imidacloprid and 
fipronil had adverse effects on the immune response of the wolf-spider Pardosa pseudoannulata, reducing significantly its phenoloxidase activity, the total number of hemocytes and encapsulation rate [282]; the implications of such effects on this natural enemy of rice pests are unknown. When applied in the egg-larval or pupal stages, acetamiprid or imidacloprid reduced the parasitisation capacity of F1 and F2 generation females of Trichogramma pretiosum on mill moth's caterpillars (Anagasta kuehniella), a pest of tomato crops [44]. Longevity of females of the parasitoid Microplitis croceipes that fed on nectar from imidacloprid-treated cotton was affected for at least 10 days after application, while the parasitoid's host foraging ability was severely affected from day 2 onwards [257]. Exposure of western subterranean termites (Reticulitermes hesperus) to acetamiprid ( $1 \mathrm{mg} / \mathrm{kg}$ sand) or imidacloprid also impaired locomotion of termites within 1 hour [230].

Bumble bees (Bombus terrestris) interrupt their activity for several hours when exposed to imidacloprid sprayed on plants [132], and soil treatment at the highest recommended doses extended the handling times of $B$. impatiens on the complex flowers [194]. Such an impairment affects the bees foraging behaviour and can result in a decreased pollination, lower reproduction and finally in colony mortality due to a lack of food [193]. Although Franklin et al. [96] found that clothianidin residues of $6 \mu \mathrm{g} / \mathrm{kg}$ in canola pollen reduced the production of queens and increased the number of males in B. impatients, their study did not find significant differences with controls due to a high variability in the results. Larval development in wild bees (Osmia lignaria and Megachile rotundata) was delayed significantly when fed pollen contaminated with either imidacloprid or clothianidin at 30 or $300 \mu \mathrm{g} / \mathrm{kg}$ [1]. Honey bees are more sensitive to neonicotinoids than bumble bees: at $6 \mu \mathrm{g} / \mathrm{kg}$, imidacloprid clearly induced a decrease in the proportion of active bees [57], and 50-500 $\mu \mathrm{g} / \mathrm{L}$ affect significantly their activity, with bees spending more time near the food source [273]. Other authors found that lower activity of honey bees during the hours following oral exposure to $100-500 \mu \mathrm{g} / \mathrm{L} \mathrm{imi-}$ dacloprid in syrup is transitory [186]. In any case, that may explain the delayed homing behaviour of honey bees exposed to $100 \mu \mathrm{g} / \mathrm{L}$ imidacloprid in syrup and their disappearance at higher doses [34, 304]. Honey bees fed on syrup contaminated with acetamiprid increased their sensitivity to antennal stimulation by sucrose solutions at doses of $1 \mu \mathrm{g} / \mathrm{bee}$ and had impaired long-term retention of olfactory learning at $0.1 \mu \mathrm{g} / \mathrm{bee}$. Contact exposure at 0.1 and $0.5 \mu \mathrm{g} /$ bee increased locomotor activity and water-induced proboscis extension reflex but had no effect on behaviour [82]. Similar response was obtained with honey bees exposed to thiomethoxam by contact, having impaired long-term retention of olfactory learning at 1 ng/bee [8]. Winter bees surviving chronic treatment with imidacloprid and its metabolite (5$\mathrm{OH}$-imidacloprid) had reduced learning performances than in summer: the lowest-effect concentration of imidacloprid was lower in summer bees $(12 \mu \mathrm{g} / \mathrm{kg})$ than in winter bees $(48$ $\mu \mathrm{g} / \mathrm{kg}$ ), indicating a greater sensitivity of honey bees behaviour in summer bees compared to winter bees [68].

Honey bees infected with the microsporidian Nosema ceranae experienced 7 or 5 times higher mortality than normal when fed syrup contaminated with sublethal doses of thiacloprid (5 $\mathrm{mg} / \mathrm{L})$ or fipronil $(1 \mu \mathrm{g} / \mathrm{L})$, respectively [293). N. ceranae is a key factor in the CCD in honey bees [127], and the synergistic effect of these systemic insecticides on Nosema is probably its 
underlying cause [213]. Suppression of the immune system is not restricted to bees, as a massive infection of medaka fish by a protozoan ectoparasite (Trichodina spp.) when exposed to imidacloprid in rice mesocosms has been documented [236].

Imidacloprid residues in water as low as $0.1 \mu \mathrm{g} / \mathrm{L}$ are sufficient to reduce head and torax length in mayfly nymphs of Baetis and Epeorus, whether applied as pulses or in continuous exposures for 20 days [6]. At $1 \mu \mathrm{g} / \mathrm{L}$ the insecticides caused feeding inhibition. However, 12$\mathrm{h}$ pulses induced emergence because of stress, whereas constant exposure reduced survivorship progressively. Also, the aquatic worm Lumbriculus variegatus experienced immobility during 4 days when exposed to $0.1-10 \mu \mathrm{g} / \mathrm{L}$ imidacloprid [5].

\subsubsection{Fipronil}

Apart from the extreme acute toxicity of this insecticide to bees, honey bees fed on sucrose syrup contaminated with fipronil $(2 \mu \mathrm{g} / \mathrm{kg})$ reduced significantly their attendance to the feeder [57]. It has also been demonstrated that sublethal concentrations of this insecticide as low as $0.5 \mathrm{ng} / \mathrm{bee}$, whether orally or topically applied, reduce the learning performance of honey bees and impair their olfactory memory but not their locomotor activity [67, 82]. Furthermore, chronic feeding exposure at $1 \mu \mathrm{g} / \mathrm{kg}$ or $0.01 \mathrm{ng} / \mathrm{bee}$ reduced learning and orientation, whilst oral treatment of $0.3 \mathrm{ng} / \mathrm{bee}$ reduced the number of foraging trips among the exposed workers [66]. In addition to their activity, honey bees fed with sucrose syrup containing $1 \mu \mathrm{g} / \mathrm{L}$ fipronil increased significantly the mortality of bees infected with the endoparasite Nosema ceranae, suggesting a synergistic effect between the insecticide and the pathogen [293]. All these sublethal effects reduce the performance of the hive and help explain the decline in honey bee and wild bee pollinators in many countries [205], although fipronil is not alone in causing this demise - neonicotinoids are equally implicated.

Female zebra finches (Taeniopygia guttata) fed with single sublethal doses of fipronil $(1,5$, and $10 \mathrm{mg} / \mathrm{kg}$ b.w.) failed to hatch 6 out of 7 eggs laid. The only chick born was underdeveloped and had fiprole residues in the brain, liver and adipose tissues. By contrast, 12day-old chicken eggs injected with fipronil ( 5.5 to $37.5 \mathrm{mg} / \mathrm{kg}$ egg weight) hatched normally although the chicks from the highest dose group showed behavioural and developmental abnormalities [145].

Low residues of fipronil in estuary waters $(0.63 \mu \mathrm{g} / \mathrm{L})$ inhibited reproduction of the copepod Amphiascus tenuiremis by $73-89 \%$, and this effect seems to be more prevalent on males than on females [45]. Even lower residue levels $(0.22 \mu \mathrm{g} / \mathrm{L})$ halted egg extrusion by $71 \%$, whereas exposure to $0.42 \mu \mathrm{g} / \mathrm{L}$ nearly eliminated reproduction ( $94 \%$ failure) on this species. Based on these results from chronic and sublethal toxicity, a three-generation Leslie matrix model predicted a $62 \%$ decline in population size of $A$. tenuiremis at only $0.16 \mu \mathrm{g} / \mathrm{L}$ [47]. Unlike other insecticides, the stress on Ceriodaphnia dubia caused by predatory cues of bluegill fish (Lepomis macrochirus) was significantly exacerbated when the cladocerans were exposed to 80-160 $\mu \mathrm{g} / \mathrm{L}$ of fipronil [223]; however, these concentrations are much higher than the residue levels usually found in waters $[99,163]$. 
While fipronil applied at the recommended rates in rice fields induces biochemical alterations in carp (Cyprinus carpio), such metabolic disturbances do not appear to have any effect on growth nor mortality of this fish after 90 days exposure at $<0.65 \mu \mathrm{g} / \mathrm{L}$ [52]. However, similar residue levels $(<1 \mu \mathrm{g} / \mathrm{L})$ reduced significantly the growth of adult medaka fish (Oryzias latipes) after two weeks of exposure, as well as growth of their offspring in the first 35 days, even if residues of fipronil by that time were below the analytical detection limit $(0.01 \mu \mathrm{g} / \mathrm{L})$ [117].

\subsubsection{Insect growth regulators}

Longevity of predatory bug Podisus maculiventris was reduced after preying on Colorado potato beetles that fed on foliage treated with novaluron at $85 \mathrm{~g} / \mathrm{ha}$. Females produced fewer eggs and their hatching was significantly suppressed, while 5th instars that also preyed on the beetles failed to moult into adults [62]. Novaluron and hexaflumuron significantly decrease $(<30 \%)$ the total protists population in the guts of termites (Reticultermes flavipes), thus upsetting their digestive homeostasis [165].

\subsection{Indirect effects on populations and communities}

Indirect effects result from the dynamics of ecosystems. Thus, applications of granular phorate to soil eliminate most soil invertebrates (see 4.1) except for Enchytraeidae worms, which increase in large numbers and take over the leaf-litter decomposition function carried out by the eliminated springtails [300].

Resurgence or induction of pests by altering the prey-predator relationships in favour of the herbivore species is most common. When carbofuran was applied to corn plantations in $\mathrm{Ni}$ caragua, the population levels of the noctuid pest Spodoptera frugiperda increased because of lesser foraging activity by predatory ants [212]. Methomyl eliminated the phytoseiid predatory mite Metaseiulus occidentalis for 10 days, thus causing an increase in Pacific spider mites (Tetranychus pacificus) and leafhopper (Eotetranychus willamettei) populations in the treated vineyards [130]. Unexpected outbreaks of a formerly innocuous herbivore mite (Tetranychus schoenei) were observed after imidacloprid applications to elms in Central Park, New York. A three-year investigation on the outbreaks showed that elimination of its predators and the enhanced fecundity of T. schoenei by this insecticide were responsible for that outcome [268].

The widespread use of insecticides usually tips the ecological balance in favour of herbivore species. For example, dimethoate sprayed on clover fields indirectly reduced the populations of house mice (Mus musculus) in the treated areas as the insect food source was depleted. However, herbivore species such as prairie voles (Microtus ochrogaster) and prairie deer mouse (Peromyscus maniculatus) increased in density levels [24], since they had more clover available due to either higher clover yields or through less competition with the house mice or both.

A reduction in arthropod populations often implies starvation of insectivorous animals. For example, densities of two species of lizards and hedgehogs in Madagascar were reduced $45-53 \%$ after spraying with fipronil to control a locust outbreak, because their favourite ter- 
mite prey was almost eliminated (80-91\%) by this chemical [214]. However, this type of indirect impact is difficult to observe and measure in birds, since they can move to other areas or change their resource diet. For example, hemlock forests treated with imidacloprid to control hemlock woolly adelgid (Adelges tsugae) reduced significantly Hemiptera and larval Lepidoptera, but not other insect taxa. Although larval Lepidoptera are the primary prey for insectivorous foliage-gleaning birds, many birds were able to find other food resources in the mixed hemlock-deciduous stands that were not treated [87]. Similarly, post-treatment with fipronil for grasshopper control in Wyoming did not affect bird densities, perhaps due to the large initial insect populations; fipronil plots generally had higher avian population densities (nongregarious, insectivores and total birds) than other areas treated with carbaryl [203]. Although some early studies found that fipronil did not have much impact on aquatic communities of Sahelian ponds [158], nor in predatory invertebrates in the Camargue marshes, herons in the latter region avoid rice fields treated with fipronil because of the scarcity of invertebrate food in there [188].

Food aversion to pesticide-treated seeds or plants is a mechanism that may indirectly ameliorate the toxic effects of systemic insecticides such as carbofuran in mice and other small rodents [170]. Some Collembola species (i.e. Folsomia fimetaria) avoid dimethoate sprayed areas [86], and female parasitoids (Cotesia vestalis) are discouraged from getting to their host -the diamond-back month (Plutella xylostella) - in turnip plants treated with methomyl, whereas clothianidin does not produce aversion [248]. Equally, dimethoate and oxydemeton-methyl sprayed on peach trees discourage honey bees from visiting in the first two days after application, while treatments with imidacloprid, acetamiprid and thiamethoxam allow honey bees visits [246]. This helps explain the high long-term impact of neonicotinoids on bees compared to the effect of OP insecticides, even if imidacloprid at high experimental concentrations in syrup (>0.5 mg/L) may also have repellent effect on honey bees [34].

\section{Risk assessment of systemic insecticides}

All systemic compounds have effects with time of exposure. However, only the persistent chemicals (fipronil, neonicotinoids, cartap and some OPs) have cumulative effects over time, since the non-persistent compounds are quickly degraded in soil and water.

For risk assessment of these compounds it is important to understand their chronic impacts. Unlike traditional protocols based on acute toxicity, the persistent activity of the parent and toxic metabolites requires that exposure time must be taken into consideration [115]. Concerns about the impacts of dietary feeding on honey bees and other non-target organisms are thus justified $[9,60,228]$, because the accumulation of small residue levels ingested repeatedly over time will eventually produce a delayed toxic effect [276]. For example, bees that feed on contaminated nectar and pollen from the treated crops are exposed to residues of imidacloprid and fipronil in the range $0.7-10 \mu \mathrm{g} / \mathrm{kg}$ and $0.3-0.4 \mu \mathrm{g} / \mathrm{kg}$ respectively [33], which appear in $11 \%$ and $48 \%$ of the pollen surveyed in France [48]. Based on those findings an estimate of the predicted environmental concentrations that bees are ingesting in that 
country can be made for each insecticide. Since there is a log-to-log linear relationship between concentration and time of exposure [234], the critical levels of residue and time of exposure can be determined.

The declining populations of predatory and parasitic arthropods after exposure to recommended applications of most systemic insecticides are worrying. In view of the above, it not so much the small concentrations they are exposed to but the time of exposure that makes the population decline progressively over weeks, months and even years of treatment, as described in this chapter. Lethal and sublethal effects on reproduction are equally implicated. This is the reason why systemic insecticides should be evaluated very carefully before using them in IPM schemes. Obviously, recovery rates are essential for the populations affected to come back, and this usually occurs by recolonisation and immigration of individuals from non-affected areas. For example, modelling based on recovery data after dimethoate application to wheat fields [277] demonstrates that a non-target organism that is reduced by only $20 \%$ but is unable to recover is likely to be far more at risk from exposure to a pesticide than an organism that is reduced $99 \%$ for a short period but has a higher recovery potential.

The above is also relevant to the impact of small residues of those systemic insecticides that have cumulative effects (e.g. neonicotinoids, fipronil and cartap) on aquatic ecosystems. Because of the short life-cycle of many zooplankton species, the negative population parameters that result from sublethal and chronic effects on such organisms can lead their local populations to extinction [260]. Immediate reductions in populations and species may not always be apparent due to the small residue concentrations and the delayed effects they cause. For example, in recent surveys of pesticide residues in freshwaters of six metropolitan areas of USA, fipronil appears regularly in certain states [254]. Fipronil and its desulfinyl, sulfide, and sulfone degradates were detected at low levels $(\leq 0.18-16 \mu \mathrm{g} / \mathrm{L})$ in estuary waters of Southern California [163], and make some 35\% of the residues found in urban waters, with a median level of $0.2-0.44 \mu \mathrm{g} / \mathrm{L}$, most frequently during the spring-summer season [99]. Imidacloprid was detected in $89 \%$ of water samples in agricultural areas of California, with 19\% exceeding the US Environmental Protection Agency's chronic invertebrate Aquatic Life Benchmark of $1.05 \mu \mathrm{g} / \mathrm{L}$ [261]. In the Netherlands, imidacloprid appeared in measurable quantities in $30 \%$ of the 4,852 water samples collected between 1998 and 2007 [287]. These figures indicate there is already a widespread contamination of waterways and estuaries with persistent systemic insecticides.

The first consequence of such contamination is the progressive reduction, and possible elimination, of entire populations of aquatic arthropods from the affected areas. As time is a critical variable in this type of assessment, it is envisaged that should this contamination continue at the current pace over the years to come the biodiversity and functionality of many aquatic ecosystems will be seriously compromised [191]. Secondly, as these organisms are a primary food source of a large number of vertebrates (e.g. fish, frogs and birds), the depletion of their main food resource will inevitably have indirect impacts on the animal populations that depend on them for their own survival. The case of the partridge in England is an example of how a combination of herbicides and insecticides can bring the demise 
of a non-target species by indirectly suppressing its food requirements [217]. Therefore, warnings about the possible role of environmental contamination with neonicotinoids in steeply declining populations of birds, frogs, hedgehogs, bats and other insectivorous animals are not far fetched and should be taken seriously [275].

\section{Conclusions}

This review has brought some light on the direct, sublethal and indirect effects that systemic insecticides have on species populations and ecosystems. Some long-term impacts have been known for some time (e.g. carbofuran, phorate), but it is the rapid increase in the usage of neonicotinoids and other systemic products that poses a new challenge to the ecological risk assessment of agrochemicals. Indeed, current risk protocols, based on acute, short-term toxic effects are inadequate to cope with the chronic exposure and cumulative, delayed impacts of the new compounds. Awareness of the increasing contamination of the environment with active residues of these chemicals should help regulators and managers to implement new approaches for risk assessment of these substances.

\section{Author details}

Francisco Sánchez-Bayo ${ }^{1 *}$, Henk A. Tennekes² and Koichi Goka ${ }^{3}$

*Address all correspondence to: sanchezbayo@mac.com

1 University of Technology Sydney, Australia

2 Experimental Toxicology Services (ETS) Nederland BV, The Netherlands

3 National Institute for Environmental Sciences, Japan

\section{References}

[1] Abbott, V. A., Nadeau, J. L., Higo, H. A., \& Winston, M. L. (2008). Lethal and sublethal effects of imidacloprid on Osmia lignaria and clothianidin on Megachile rotundata (Hymenoptera: Megachilidae). J. Econ. Entomol., 101(3), 784-796.

[2] Agritox. (2002). Liste des substances actives. Paris, France: Institut National de la Recherche Agronomique.

[3] Al-Antary, T. M., Ateyyat, M. A., \& Abussamin, B. M. (2010). Toxicity of certain insecticides to the parasitoid Diaeretiella rapae (Mcintosh) (Hymenoptera: Aphidiidae) 
and its host, the cabbage aphid Brevicoryne brassicae L. (Homoptera: Aphididae). Aust. J. Basic Appl. Sci., 4(6), 994-1000.

[4] Al-Haifi, M. A., Khan, M. Z., Murshed, V. A., \& Ghole, S. (2006). Effect of dimethoate residues on soil micro-arthropods population in the valley of Zendan, Yemen. $J$. Appl. Sci. Environ. Manage., 10(2), 37-41.

[5] Alexander, A. C., Culp, J. M., Liber, K., \& Cessna, A. J. (2007). Effects of insecticide exposure on feeding inhibition in mayflies and oligochaetes. Environ. Toxicol. Chem., 26(8), 1726-1732.

[6] Alexander, A. C., Heard, K. S., \& Culp, J. M. (2008). Emergent body size of mayfly survivors. Freshwat. Biol., 53(1), 171-180.

[7] Ali, A., \& Stanley, B. H. (1982). Effects of a new carbamate insecticide, Larvin (UC-51762), on some nontarget aquatic invertebrates. Florida Entomol., 65(4), 477-483.

[8] Aliouane, Y., El -Hassani, A. K., Gary, V., Armengaud, C., Lambin, M., \& Gauthier, M. (2009). Subchronic exposure of honeybees to sublethal doses of pesticides: effects on behavior. Environ. Toxicol. Chem., 28(1), 113-122.

[9] Alix, A., \& Vergnet, C. (2007). Risk assessment to honey bees: a scheme developed in France for non-sprayed systemic compounds. Pest Manage. Sci., 63(11), 1069-1080.

[10] Anoop, K., \& Ram, S. (2012). Effect of biopesticides and insecticides on aphid population, bee visits and yield of mustard. Ann. Plant Protect. Sci., 20(1), 206-209.

[11] Araya, J. E., Araya, M., \& Guerrero, M. A. (2010). Effects of some insecticides applied in sublethal concentrations on the survival and longevity of Aphidius ervi (Haliday) (Hymenoptera: Aphidiidae) adults. Chilean J. Agric. Res., 70(2), 221-227.

[12] Armbrust, K. L., \& Peeler, H. B. (2002). Effects of formulation on the run-off of imidacloprid from turf. Pest Manage. Sci., 58(7), 702-706.

[13] Arnold, H., Pluta, H. J., \& Braunbeck, T. (1995). Simultaneous exposure of fish to endosulfan and disulfoton in vivo: ultrastructural, stereological and biochemical reactions in hepatocytes of male rainbow trout (Oncorhynchus mykiss). Aquat. Toxicol., 33, 17-34.

[14] Ateyyat, M. (2012). Selectivity of four insecticides to woolly apple aphid, Eriosoma lanigerum (Hausmann) and its sole parasitoid, Aphelinus mali (Hald.). World Appl. Sci. J., 16(8), 1060-1064.

[15] Azizullah, A., Richter, P., \& Häder, D. P. (2011). Comparative toxicity of the pesticides carbofuran and malathion to the freshwater flagellate Euglena gracilis. Ecotoxicology, 20(6), 1442-1454.

[16] Babu, B. S., \& Gupta, G. P. (1986). Effect of systemic insecticides on the population of soil arthropods in a cotton field. J. Soil Biol. Ecol., 6(1), 32-41. 
[17] Babu, B. S., \& Gupta, G. P. (1988). Efficacy of systemic insecticides against cotton jassid (Amrasca devastans) and their effect on non-target organisms in upland cotton (Gossypium hirsutum). Indian J. Agric. Sci., 58(6), 496-499.

[18] Balanca, G., \& Visscher, M. N.d. (1997). Effects of very low doses of fipronil on grasshoppers and non-target insects following field trials for grasshopper control. Crop Protection, 16, 553-564.

[19] Balcomb, R., Bowen, C. I., Wright, D., \& Law, M. (1984). Effects on wildlife of atplanting corn applications of granular carbofuran. J. Wildl. Manage., 48(4), 1353-1359.

[20] Balconi, C., Mazzinelli, G., \& Motto, M. (2011). Neonicotinoid insecticide seed coatings for the protection of corn kernels and seedlings, and for plant yield. Maize Genetics Cooperation Newsletter [84], 3.

[21] Banks, J. E., \& Stark, J. D. (2011). Effects of a nicotinic insecticide, imidacloprid, and vegetation diversity on movement of a common predator, Coccinella septempunctata Biopestic. Int. 7(2), 113-122.

[22] Barahona, M. V., \& Sánchez-Fortún, S. (1999). Toxicity of carbamates to the brine shrimp Artemia salina and the effect of atropine, BW284c51, iso-OMPA and 2-PAM on carbaryl toxicity. Environ. Pollut., 104(3), 469-476.

[23] Barbee, G. C., \& Stout, M. J. (2009). Comparative acute toxicity of neonicotinoid and pyrethroid insecticides to non-target crayfish (Procambarus clarkii) associated with rice-crayfish crop rotations. Pest Manage. Sci., 65(11), 1250-1256.

[24] Barrett, G. W., \& Darnell, R. M. (1967). Effects of dimethoate on small mammal populations. Am. Midland Nat., 77, 164-175.

[25] Baur, M. E., Ellis, J., Hutchinson, K., \& Boethel, D. J. (2003). Contact toxicity of selective insecticides for non-target predaceous hemipterans in soybeans. J. Entomol. Sci., 38(2), 269-277.

[26] Begum, G. (2004). Carbofuran insecticide induced biochemical alterations in liver and muscle tissues of the fish Clarias batrachus (linn) and recovery response. Aquat. Toxicol., 66(1), 83-92.

[27] Beketov, M., Schafer, R. B., Marwitz, A., Paschke, A., \& Liess, M. (2008). Long-term stream invertebrate community alterations induced by the insecticide thiacloprid: effect concentrations and recovery dynamics. Sci. Total Environ., 405, 96-108.

[28] Beketov, M. A., \& Liess, M. (2008). Acute and delayed effects of the neonicotinoid insecticide thiacloprid on seven freshwater arthropods. Environ. Toxicol. Chem., 27(2), 461-470.

[29] Belfroid, A. C., van Drunen, M., Beek, M. A., Schrap, S. M., van Gestel, C. A. M., \& van Hattum, B. (1998). Relative risks of transformation products of pesticides for aquatic ecosystems. Sci. Total Environ., 222(3), 167-183. 
[30] Bellows, T. S., Morse, J. G., Gaston, L. K., \& Bailey, J. B. (1988). The fate of two systemic insecticides and their impact on two phytophagous and a beneficial arthropod in a citrus agroecosystem. J. Econ. Entomol., 81(3), 899-904.

[31] Berg, H. (2001). Pesticide use in rice and rice-fish farms in the Mekong Delta, Vietnam. Crop Protection, 20(10), 897-905.

[32] Bluemel, S., \& Stolz, M. (1993). Investigations on the effect of insect growth regulators and inhibitors on the predatory mite Phytoseiulus persimilis A.H. with particular emphasis on cyromazine. Zeitschrift fuer Pflanzenkrankheiten und Pflanzenschutz, 100(2), 150-154.

[33] Bonmatin, J. M., Marchand, P. A., Cotte, J. F., Aajoud, A., Casabianca, H., Goutailler, G., \& Courtiade, M. (2007). Bees and systemic insecticides (imidacloprid, fipronil) in pollen: subnano-quantification by HPLC/MS/MS and GC/MS. Environmental fate and ecological effects of pesticides, Re, A.A.M.d. et al., editors, 827-834, 978-8-87830-473-4.

[34] Bortolotti, L., Montanari, R., Marcelino, J., Medrzycki, P., Maini, S., \& Porrini, C. (2003). Effects of sublethal imidacloprid doses on the homing rate and foraging activity of honey bees. Bull. Insectology, 56(1), 63-67.

[35] Bottger, R., Schaller, J., \& Mohr, S. (2012). Closer to reality - the influence of toxicity test modifications on the sensitivity of Gammarus roeseli to the insecticide imidacloprid. Ecotoxicol. Environ. Saf., 81(0), 49-54.

[36] Brasel, J., Collier, A., \& Pritsos, C. (2007). Differential toxic effects of carbofuran and diazinon on time of flight in pigeons (Columba livia): potential for pesticide effects on migration. Toxicol. Appl. Pharmacol., 219(2-3), 241-246.

[37] Bringolf, R. B., Cope, W. G., Eads, C. B., Lazaro, P. R., Barnhart, M. C., \& Shea, D. (2007). Acute and chronic toxicity of technical-grade pesticides to glochidia and juveniles of freshwater mussels (Unionidae). Environ. Toxicol. Chem., 26(10), 2094-2100.

[38] Brunet, R., Girard, C., \& Cyr, A. (1997). Comparative study of the signs of intoxication and changes in activity level of red-winged blackbirds (Agelaius phoeniceus) exposed to dimethoate. Agric. Ecosyst. Environ., 64, 201-209.

[39] Brunetto, R., Burguera, M., \& Burguera, J. L. (1992). Organophosphorus pesticide residues in some watercourses from Merida, Venezuela. Sci. Total Environ., 114, 195-204.

[40] Buckingham, S., Lapied, B., Corronc, H., \& Sattelle, F. (1997). Imidacloprid actions on insect neuronal acetylcholine receptors. J. Exp. Biol., 200(21), 2685-2692.

[41] Bunyan, P. J., Heuvel, M. J.v.d, Stanley, P. I., \& Wright, E. N. (1981). An intensive field trial and a multi-site surveillance exercise on the use of aldicarb to investigate methods for the assessment of possible environmental hazards presented by new pesticides. Agro-Ecosystems, 7(3), 239-262. 
[42] Campiche, S., L'Arnbert, G., Tarradellas, J., \& Becker-van, Slooten. K. (2007). Multigeneration effects of insect growth regulators on the springtail Folsomia candida. Ecotoxicol. Environ. Saf., 67(2), 180-189.

[43] Capowiez, Y., Bastardie, F., \& Costagliola, G. (2006). Sublethal effects of imidacloprid on the burrowing behaviour of two earthworm species: modifications of the 3D burrow systems in artificial cores and consequences on gas diffusion in soil. Soil Biol. Biochem., 38(2), 285-293.

[44] Carvalho, G. A., Godoy, M. S., Parreira, D. S., \& Rezende, D. T. (2010). Effect of chemical insecticides used in tomato crops on immature Trichogramma pretiosum (Hymenoptera: Trichogrammatidae). Revista Colombiana de Entomologia, 36(1), 10-15.

[45] Cary, T. L., Chandler, G. T., Volz, D. C., Walse, S. S., \& Ferry, J. L. (2003). Phenylpyrazole insecticide fipronil induces male infertility in the estuarine meiobenthic crustacean Amphiascus tenuiremis. Environ. Sci. Technol., 38(2), 522-528.

[46] Chai, L. K., Wong, M. H., Mohd-Tahir, N., \& Hansen, H. C. B. (2010). Degradation and mineralization kinetics of acephate in humid tropic soils of Malaysia. Chemosphere, 79(4), 434-440.

[47] Chandler, G. T., Cary, T. L., Volz, D. C., Walse, S. S., Ferry, J. L., \& Klosterha, S. L. (2004). Fipronil effects on estuarine copepod (Amphiascus tenuiremis) development, fertility, and reproduction: a rapid life-cycle assay in 96-well microplate format. Environ. Toxicol. Chem., 23(1), 117-124.

[48] Chauzat, M., , P., Martel, A. C., Cougoule, N., Porta, P., Lachaize, J., Zeggane, S., Aubert, M., Carpentier, P., Faucon, J., \& , P. (2011). An assessment of honeybee colony matrices, Apis mellifera (Hymenoptera: Apidae) to monitor pesticide presence in continental France. Environ. Toxicol. Chem., 30(1), 103-111.

[49] Chen, X. D., Culbert, E., Hebert, V., \& Stark, J. D. (2010). Mixture effects of the nonylphenyl polyethoxylate, R-11 and the insecticide, imidacloprid on population growth rate and other parameters of the crustacean, Ceriodaphnia dubia. Ecotoxicol. Environ. Saf., 73(2), 132-137.

[50] Choo, H. Y., Kim, H. H., \& Kaya, H. K. (1998). Effects of selected chemical pesticides on Agamermis unka (Nematoda: Mermithidae), a parasite of the brown plant hopper, Nilaparvata lugens. Biocontrol Sci. Technol. , 8(3), 413-427.

[51] Christin, M. S., Gendron, A. D., Brousseau, P., Ménard, L., Marcogliese, D. J., Cyr, D., Ruby, S., \& Fournier, M. (2003). Effects of agricultural pesticides on the immune system of Rana pipiens and on its resistance to parasitic infection. Environ. Toxicol. Chem., 22(5), 1127-1133.

[52] Clasen, B., Loro, V. L., Cattaneo, R., Moraes, B., Lopes, T., Avila, L., A.d, , Zanella, R., Reimche, G. B., \& Baldisserotto, B. (2012). Effects of the commercial formulation containing fipronil on the non-target organism Cyprinus carpio: implications for rice-fish cultivation. Ecotoxicol. Environ. Saf., 77, 45-51. 
[53] Clements, R. O., Bentley, B. R., \& Jackson, C. A. (1986). The impact of granular formulations of phorate, terbufos, carbofuran, carbosulfan and thiofanox on newly sown Italian ryegrass, Lolium multiflorum. Crop Protection, 5(6), 389-394.

[54] Cloyd, R. A., \& Bethke, J. A. (2011). Impact of neonicotinoid insecticides on natural enemies in greenhouse and interiorscape environments. Pest Manage. Sci., 67(1), 3-9.

[55] Cockfield, S. D., \& Potter, D. A. (1983). Short-term effects of insecticidal applications on predaceous arthropods and oribatid mites in Kentucky blue grass turf. Environ. Entomol., 12(4), 1260-1264.

[56] Cole, L. M., Nicholson, R. A., \& Casida, J. E. (1993). Action of phenylpyrazole insecticides at the GABA-gated chloride channel. Pestic. Biochem. Physiol., 46(1), 47-54.

[57] Colin, M. E., Bonmatin, J. M., Moineau, I., Gaimon, C., Brun, S., \& Vermandere, J. P. (2004). A method to quantify and analyze the foraging activity of honey bees: relevance to the sublethal effects induced by systemic insecticides. Arch. Environ. Contam. Toxicol., 47(3), 387-395.

[58] Colinas, C., Ingham, E., \& Molina, R. (1994). Population responses of target and nontarget forest soil organisms to selected biocides. Soil Biol. Biochem., 26(1), 41-47.

[59] Cortet, J., \& Poinsot-Balaguer, N. (2000). Impact of phytopharmaceutical products on soil microarthropods in an irrigated maize field: The use of the litter bag method. Can. J. Soil Sci., 80(2), 237-249.

[60] Cresswell, J. (2011). A meta-analysis of experiments testing the effects of a neonicotinoid insecticide (imidacloprid) on honey bees. Ecotoxicology, 20(1), 149-157.

[61] Cutler, G. C., \& Scott-Dupree, C. D. (2007). Exposure to clothianidin seed-treated canola has no long-term impact on honey bees. J. Econ. Entomol., 100(3), 765-772.

[62] Cutler, G. C., Scott-Dupree, C. D., Tolman, J. H., \& Harris, C. R. (2006). Toxicity of the insect growth regulator novaluron to the non-target predatory bug Podisus maculiventris (Heteroptera: Pentatomidae). Biol. Control, 38(2), 196-204.

[63] Dai, Y., Ji, W., Chen, T., Zhang, W., Liu, Z., Ge, F., \& Yuan, S. (2010). Metabolism of the neonicotinoid insecticides acetamiprid and thiacloprid by the yeast Rhodotorula mucilaginosa strain IM-2. J. Agric. Food Chem., 58(4), 2419-2425.

[64] Dastjerdi, H. R., Hejazi, M. J., Ganbalani, G. N., \& Saber, M. (2008). Toxicity of some biorational and conventional insecticides to cotton bollworm, Helicoverpa armigera (Lepidoptera: Noctuidae) and its ectoparasitoid, Habrobracon hebetor (Hymenoptera: Braconidae). J. Entomol. Soc. Iran, 28(1), 27-37.

[65] Decarie, R., Des, Granges. J. L., Lepine, C., \& Morneau, F. (1993). Impact of insecticides on the American robin (Turdus migratorius) in a suburban environment. Environ. Pollut., 80, 231-238. 
[66] Decourtye, A., Devillers, J., Aupinel, P., Brun, F., Bagnis, C., Fourrier, J., \& Gauthier, M. (2011). Honeybee tracking with microchips: a new methodology to measure the effects of pesticides. Ecotoxicology, 20(2), 429-437.

[67] Decourtye, A., Devillers, J., Genecque, E., Menach, K. L., Budzinski, H., Cluzeau, S., \& Pham-Delègue, M. H. (2005). Comparative sublethal toxicity of nine pesticides on olfactory learning performances of the honeybee Apis mellifera. Arch. Environ. Contam. Toxicol., 48(2), 242-250.

[68] Decourtye, A., Lacassie, E., \& Pham-Delègue, M. H. (2003). Learning performances of honeybees (Apis mellifera L) are differentially affected by imidacloprid according to the season. Pest Manage. Sci., 59(3), 269-278.

[69] Desneux, N., Decourtye, A., Delpuech, J., \& , M. (2007). The sublethal effects of pesticides on beneficial arthropods. Annu. Rev. Entomol., 52, 81-106.

[70] Dewar, A. M., Haylock, L. A., Garner, B. H., Sands, R. J. N., \& Pilbrow, J. (2005). Neonicotinoid seed treatments - the panacea for most pest problems in sugar beet. Aspects Appl. Biol. [76], 3-12.

[71] Dhadialla, T. S., Carlson, G. R., \& Le , D. P. (1998). New insecticides with ecdysteroidal and juvenile hormone activity. Annu. Rev. Entomol., 43(1), 545-569.

[72] Dieter, C. D., Duffy, W. G., \& Flake, L. D. (1996). The effect of phorate on wetland macroinvertebrates. Environ. Toxicol. Chem., 15(3), 308-312.

[73] Dieter, C. D., Flake, L. D., \& Duffy, W. G. (1995). Effects of phorate on ducklings in northern prairie wetlands. J. Wildl. Manage., 59(3), 498-505.

[74] Dittbrenner, N., Triebskorn, R., Moser, I., \& Capowiez, Y. (2010). Physiological and behavioural effects of imidacloprid on two ecologically relevant earthworm species (Lumbricus terrestris and Aporrectodea caliginosa). Ecotoxicology, 19, 1567-1573.

[75] Drescher, W., \& Geusen-Pfister, H. (1991). Comparative testing of the oral toxicity of acephate, dimethoate and methomyl to honeybees, bumblebees and Syrphidae. Acta Horticulturae, 288, 133-138.

[76] Easterbrook, M. A. (1997). A field assessment of the effects of insecticides on the beneficial fauna of strawberry. Crop Protection, 16(2), 147-152.

[77] Ecoli, C. C., Moraes, J. C., \& Vilela, M. (2010). Suplementos alimentares e isca toxica no manejo do bicho-mineiro e de seus inimigos naturais. Coffee Sci., 5(2), 167-172.

[78] Eisenback, B. M., Salom, S. M., Kok, L. T., \& Lagalante, A. F. (2010). Lethal and sublethal effects of imidacloprid on hemlock woolly adelgid (Hemiptera: Adelgidae) and two introduced predator species. J. Econ. Entomol., 103(4), 1222-34.

[79] Eisenhauer, N., Klier, M., Partsch, S., Sabais, A. C. W., Scherber, C., Weisser, W. W., \& Scheu, S. (2009). No interactive effects of pesticides and plant diversity on soil microbial biomass and respiration. Appl. Soil Ecol., 42(1), 31-36. 
[80] El -Din, H. A. S., \& Girgis, N. R. (1997). Susceptibility of honey bee workers, Apis mellifera L. to nine different insecticides. Ann. Agric. Sci. Moshtohor, 35(4), 2571-2582.

[81] El -Hassani, A. K., Dacher, M., Gary, V., Lambin, M., Gauthier, M., \& Armengaud, C. (2008). Effects of sublethal doses of acetamiprid and thiamethoxam on the behavior of the honeybee (Apis mellifera). Arch. Environ. Contam. Toxicol., 54(4), 653-661.

[82] El -Hassani, A. K., Dacher, M., Gauthier, M., \& Armengaud, C. (2005). Effects of sublethal doses of fipronil on the behavior of the honeybee (Apis mellifera). Pharmacol. Biochem. Behavior, 82(1), 30-39.

[83] Elbert, A., Haas, M., Springer, B., Thielert, W., \& Nauen, R. (2008). Applied aspects of neonicotinoid uses in crop protection. Pest Manage. Sci., 64(11), 1099-1105.

[84] Elliott, J. E., Wilson, L. K., Langelier, K. M., Mineau, P., \& Sinclair, P. H. (1997). Secondary poisoning of birds of prey by the organophosphorus insecticide, phorate. Ecotoxicology, 6(4), 219-231.

[85] Endlweber, K., Schädler, M., \& Scheu, S. (2005). Effects of foliar and soil insecticide applications on the collembolan community of an early set-aside arable field. Appl. Soil Ecol., 31(1-2), 136-146.

[86] Fabian, M., \& Petersen, H. (1994). Short-term effects of the insecticide dimethoate on activity and spatial distribution of a soil inhabiting collembolan Folsomia fimetaria Linne (Collembola:Isotomidae). Pedobiologia, 38(4), 289-302.

[87] Falcone, J. F., \& De Wald, L. E. (2010). Comparisons of arthropod and avian assemblages in insecticide-treated and untreated eastern hemlock (Tsuga canadensis L. Carr) stands in Great Smoky Mountains National Park, USA. Forest Ecol. Manage., 260(5), 856-863.

[88] Farinos, G. P., de la Poza, M., Hernandez-Crespo, P., Ortego, F., \& Castanera, P. (2008). Diversity and seasonal phenology of aboveground arthropods in conventional and transgenic maize crops in Central Spain. Biol. Control, 44(3), 362-371.

[89] Faucon, J. P., Aurières, C., Drajnudel, P., Mathieu, L., Ribière, M., Martel, A. C., Zeggane, S., Chauzat, M. P., \& Aubert, M. F. A. (2005). Experimental study on the toxicity of imidacloprid given in syrup to honey bee (Apis mellifera) colonies. Pest Manage. Sci., 61(2), 111-125.

[90] Fernandes, M., E.d, S., Fernandes, F. L., Picanco, M. C., Queiroz, R. B., Silva, R. S.d, \& Huertas, A. A. G. (2008). Physiological selectivity of insecticides to Apis mellifera (Hymenoptera: Apidae) and Protonectarina sylveirae (Hymenoptera: Vespidae) in citrus. Sociobiology, 51(3), 765-774.

[91] Fleming, W., \& Bradbury, S. (1981). Recovery of cholinesterase activity in mallard ducklings administered organophosphorus pesticides. J. Toxicol. Environ. Health B, 8(5-6), 885-97. 
[92] Flickinger, E. L., White, D. H., Mitchell, C. A., \& Lamont, T. G. (1984). Monocrotophos and dicrotophos residues in birds as a result of misuse of organophosphates in Matagorda County, Texas. J.A.O.A.C., 67, 827-828.

[93] Fluetsch, K. M., \& Sparling, D. W. (1994). Avian nesting success and diversity in conventionally and organically managed apple orchards. Environ. Toxicol. Chem., 13(10), 1651-1659.

[94] Fowle, C. D. (1966). The effects of phosphamidon on birds in New Brunswick forests. J. Appl. Ecol., 3, 169-170.

[95] Frampton, G. K., Brink, P., \& J.v.d, . (2007). Collembola and macroarthropod community responses to carbamate, organophosphate and synthetic pyrethroid insecticides: direct and indirect effects. Environ. Pollut., 147(1), 14-25.

[96] Franklin, M. T., Winston, M. L., \& Morandin, L. A. (2004). Effects of clothianidin on Bombus impatiens (Hymenoptera: Apidae) colony health and foraging ability. J. Econ. Entomol., 97(2), 369-373.

[97] Freuler, J., Blandenier, G., Meyer, H., \& Pignon, P. (2001). Epigeal fauna in a vegetable agroecosystem. Mitteilungen der Schweizerischen Entomologischen Gesellschaft, $74(1-2), 17-42$.

[98] Furlong, M. J., Verkerk, R. H. J., \& Wright, D. J. (1994). Differential effects of the acylurea insect growth regulator teflubenzuron on the adults of two endolarval parasitoids of Plutella xylostella, Cotesia plutellae and Diadegma semiclausum. Pestic. Sci. , 41(4), 359-364.

[99] Gan, J., Bondarenko, S., Oki, L., Haver, D., \& Li, J. X. (2012). Occurrence of fipronil and its biologically active derivatives in urban residential runoff. Environ. Sci. Technol., 46(3), 1489-1495.

[100] Gao, J., Garrison, A. W., Hoehamer, C., Mazur, C. S., \& Wolfe, N. L. (2000). Uptake and phytotransformation of organophosphorus pesticides by axenically cultivated aquatic plants. J. Agric. Food Chem., 48, 6114-6120.

[101] Gendron, A. D., Marcogliese, D. J., Barbeau, S., Christin, M. S., Brousseau, P., Ruby, S., Cyr, D., \& Fournier, M. (2003). Exposure of leopard frogs to a pesticide mixture affects life history characteristics of the lungworm Rhabdias ranae. Oecologia, 135, 469-476.

[102] Georgiadis, P. T., Pistorius, J., \& Heimbach, U. (2010). Vom Winde verweht- Abdrift von Beizstauben- ein Risiko fur Honigbienen (Apis mellifera L.)? Julius-Kuhn-Archiv [424], 33.

[103] Ghodageri, M. G., \& Katti, P. (2011). Morphological and behavioral alterations induced by endocrine disrupters in amphibian tadpoles. Toxicol. Environ. Chem., 93(10), 2012-2021. 
[104] Giglio, A., Giulianini, P. G., Zetto, T., \& Talarico, F. (2011). Effects of the pesticide dimethoate on a non-target generalist carabid, Pterostichus melas italicus (Dejean, 1828) (Coleoptera: Carabidae). Italian J. Zool., 78(4), 471-477.

[105] Girolami, V., Marzaro, M., Vivan, L., Mazzon, L., Greatti, M., Giorio, C., Marton, D., \& Tapparo, A. (2012). Fatal powdering of bees in flight with particulates of neonicotinoids seed coating and humidity implication. J. Appl. Entomol., 136(1/2), 17-26.

[106] Goldman, L. R., Smith, D. F., \& Neutra, R. R. (1990). Pesticide food poisoning from contaminated watermelons in California, 1985. Arch. Environ. Health, 45(4), 229-236.

[107] Golombieski, J. I., Marchesan, E., Baumart, J. S., Reimche, G. B., Junior, C. R., Storck, L., \& Santos, S. (2008). Cladocera, Copepoda e Rotifera em rizipiscicultura tratada com os herbicidas metsulfuron-metílico e azimsulfuron e o inseticida carbofuran. Ciencia Rural, 38(8), 2097-2102.

[108] Gomez-Eyles, J. L., Svendsen, C., Lister, L., Martin, H., Hodson, M. E., \& Spurgeon, D. J. (2009). Measuring and modelling mixture toxicity of imidacloprid and thiacloprid on Caenorhabditis elegans and Eisenia fetida. Ecotoxicol. Environ. Saf., 72(1), 71-79.

[109] Gour, I. S., \& Pareek, B. L. (2005). Relative toxicity of some insecticides to coccinellid, Coccinella septempunctata Linn. and Indian honey bee, Apis cerana indica. Indian J. Agric. Res., 39(4), 299-302.

[110] Grafton-Cardwell, E. E., \& Gu, P. (2003). Conserving vedalia beetle, Rodolia cardinalis (Mulsant) (Coleoptera: Coccinellidae), in citrus: A continuing challenge as new insecticides gain registration. J. Econ. Entomol., 96(5), 1388-1398.

[111] Gregorc, A., \& Bozic, J. (2004). Is honey bee colonies mortality related to insecticide use in agriculture? [Ali cebelje druzine odmirajo zaradi uporabe insekticida v kmetijstvu?]. Sodobno Kmetijstvo, 37(7), 29-32.

[112] Grout, T. G., Richards, G. I., \& Stephen, P. R. (1997). Further non-target effects of citrus pesticides on Euseius addoensis and Euseius citri (Acari: Phytoseiidae). Exp. Appl. Acarol., 21(3), 171-177.

[113] Grue, C. E., Powell, G. V. N., \& Mc Chesney, M. J. (1982). Care of nestlings by wild female starlings exposed to an organophosphate pesticide. J. Appl. Ecol., 19, 327-335.

[114] Grue, C. E., \& Shipley, B. K. (1984). Sensitivity of nestling and adult starlings to dicrotophos, an organophosphate pesticide. Environ. Res., 35(2), 454-465.

[115] Halm, M. P., Rortais, A., Arnold, G., Taséi, J. N., \& Rault, S. (2006). New risk assessment approach for systemic insecticides: the case of honey bees and imidacloprid (Gaucho). Environ. Sci. Technol., 40(7), 2448-2454.

[116] Hawthorne, D. J., \& Dively, G. P. (2011). Killing them with kindness? In-hive medications may inhibit xenobiotic efflux transporters and endanger honey bees. PLoS One, (November), e26796. 
[117] Hayasaka, D., Korenaga, T., Sánchez-Bayo, F., \& Goka, K. (2012a). Differences in ecological impacts of systemic insecticides with different physicochemical properties on biocenosis of experimental paddy fields. Ecotoxicology, 21(1), 191-201.

[118] Hayasaka, D., Korenaga, T., Suzuki, K., Saito, F., Sánchez-Bayo, F., \& Goka, K. (2012b). Cumulative ecological impacts of two successive annual treatments of imidacloprid and fipronil on aquatic communities of paddy mesocosms. Ecotoxicol. Environ. Saf., 80, 355-362.

[119] Hayasaka, D., Korenaga, T., Suzuki, K., Sánchez-Bayo, F., \& Goka, K. (2012c). Differences in susceptibility of five cladoceran species to two systemic insecticides, imidacloprid and fipronil. Ecotoxicology, 21(2), 421-427.

[120] He, Y., Zhao, J., Zheng, Y., Desneux, N., \& Wu, K. (2012). Lethal effect of imidacloprid on the coccinellid predator Serangium japonicum and sublethal effects on predator voracity and on functional response to the whitefly Bemisia tabaci. Ecotoxicology, $1-10$.

[121] Heath, A. G., Joseph, J., Cech, J., Brink, L., Moberg, P., \& Zinkl, J. G. (1997). Physiological responses of fathead minnow larvae to rice pesticides. Ecotoxicol. Environ. Saf., 37(3), 280-288.

[122] Heinrichs, E. A., Aquino, G. B., Chelliah, S., Valencia, S. L., \& Reissig, W. H. (1982). Resurgence of Nilaparvata lugens (Stal) populations as influenced by method and timing of insecticide applications in lowland rice. Environ. Entomol., 11(1), 78-84.

[123] Hela, D. G., Lambropoulou, D. A., Konstantinou, I. K., \& Albanis, T. A. (2005). Environmental monitoring and ecological risk assessment for pesticide contamination and effects in Lake Pamvotis, northwestern Greece. Environ. Toxicol. Chem., 24(6), 1548-1556.

[124] Held, D. W., \& Parker, S. (2011). Efficacy of soil applied neonicotinoid insecticides against the azalea lace bug, Stephanitis pyrioides, in the landscape. Florida Entomol., 94(3), 599-607.

[125] Henry, M.l., Beguin, M., Requier, F., Rollin, O., Odoux, J. F.o, Aupinel, P., Aptel, J., Tchamitchian, S., \& Decourtye, A. (2012). A common pesticide decreases foraging success and survival in honey bees. Science, 336, 348-350.

[126] Heong, K. L., Escalada, M. M., \& Mai, V. (1994). An analysis of insecticide use in rice: case studies in the Philippines and Vietnam. Int. J. Pest Manage., 40(2), 173-178.

[127] Higes, M., Martín-Hernández, R., Martínez-Salvador, A., Garrido-Bailón, E., González-Porto, A. V., Meana, A., Bernal, J. L., Del Nozal, M. J., \& Bernal, J. (2010). A preliminary study of the epidemiological factors related to honey bee colony loss in Spain. Environ. Microbiol. Rep., 2(2), 243-250.

[128] Hohreiter, D. W., Reinert, R. E., \& Bush, P. B. (1991). Effects of the insecticides carbofuran and fenvalerate on adenylate parameters in bluegill sunfish (Lepomis macrochirus). Arch. Environ. Contam. Toxicol., 21(3), 325-331. 
[129] Hoshino, T., \& Takase, I. (1993). New insecticide imidacloprid - Safety assessment. Noyaku Kenkyu, 39(3), 37-45.

[130] Hoy, M. A., Flaherty, D., Peacock, W., \& Culver, D. (1979). Vineyard and laboratory evaluations of methomyl, dimethoate and permethrin for a grape pest management program in the San Joaquin Valley of California, USA. J. Econ. Entomol., 72(2), 250-255.

[131] Huusela-Veistola, E. (2000). Effects of pesticide use on non-target arthropods in a Finnish cereal field. Aspects Appl. Biol. [62], 67-72.

[132] Incerti, F., Bortolotti, L., Porrini, C., Sbrenna, A. M., \& Sbrenna, G. (2003). An extended laboratory test to evaluate the effects of pesticides on bumblebees. Preliminary results. Bull. Insectology, 56(1), 159-164.

[133] Ingham, E. R., Coleman, D. C., \& Crossley, D. A. Jr. (1994). Use of sulfamethoxazolepenicillin, oxytetracycline, carbofuran, carbaryl, naphthalene and Temik to remove key organism groups in soil in a corn agroecosystem. J. Sustain. Agric., 4(3), 7-30.

[134] Iwasa, T., Motoyama, N., Ambrose, J. T., \& Roe, R. M. (2004). Mechanism for the differential toxicity of neonicotinoid insecticides in the honey bee, Apis mellifera. Crop Protection, 23(5), 371-378.

[135] Jansen, J. P. (2000). A three-year field study on the short-term effects of insecticides used to control cereal aphids on plant-dwelling aphid predators in winter wheat. Pest Manage. Sci., 56(6), 533-539.

[136] Jemec, A., Tisler, T., Drobne, D., Sepcifá, K., Fournier, D., \& Trebse, P. (2007). Comparative toxicity of imidacloprid, of its commercial liquid formulation and of diazinon to a non-target arthropod, the microcrustacean Daphnia magna. Chemosphere, 68(8), 1408-18.

[137] Jeschke, P., Nauen, R., Schindler, M., \& Elbert, A. (2010). Overview of the status and global strategy for neonicotinoids. J. Agric. Food Chem., 59(7), 2897-2908.

[138] Jinguji, H., Thuyet, D., Ueda, T., \& Watanabe, H. (2012). Effect of imidacloprid and fipronil pesticide application on Sympetrum infuscatum (Libellulidae: Odonata) larvae and adults. Paddy Water Environ., online first:, 1-8.

[139] Johansson, M., Piha, H., Kylin, H., \& Merilä, J. (2006). Toxicity of six pesticides to common frog (Rana temporaria) tadpoles. Environ. Toxicol. Chem., 25(12), 3164-3170.

[140] Johnson, B. T. (1986). Potential impact of selected agricultural chemical contaminants on a northern prairie wetland: a microcosm evaluation. Environ. Toxicol. Chem., 5(5), 473-485.

[141] Joy, V. C., \& Chakravorty, P. P. (1991). Impact of insecticides on nontarget microarthropod fauna in agricultural soil. Ecotoxicol. Environ. Saf., 22(1), 8-16. 
[142] Kanungo, P. K., Adhya, T. K., \& Rao, V. R. (1995). Influence of repeated applications of carbofuran on nitrogenase activity and nitrogen-fixing bacteria associated with rhizosphere of tropical rice. Chemosphere, 31(5), 3249-3257.

[143] Karnatak, A. K., \& Thorat, P. V. (2006). Effect of insecticidal micro-environment on the honey bee, Apis mellifera in Brassica napus. J. Appl. Biosci., 32(1), 93-94.

[144] Kennedy, P. J., Conrad, K. F., Perry, J. N., Powell, D., Aegerter, J., Todd, A. D., Walters, K. F. A., \& Powell, W. (2001). Comparison of two field-scale approaches for the study of effects of insecticides on polyphagous predators in cereals. Appl. Soil Ecol., 17(3), 253-266.

[145] Kitulagodage, M., Buttemer, W., \& Astheimer, L. (2011). Adverse effects of fipronil on avian reproduction and development: maternal transfer of fipronil to eggs in zebra finch Taeniopygia guttata and in ovo exposure in chickens Gallus domesticus. Ecotoxicology, 20(4), 653-660.

[146] Kjaer, C., Elmegaard, N., Axelsen, J. A., Andersen, P. N., \& Seidelin, N. (1998). The impact of phenology, exposure and instar susceptibility on insecticide effects on a chrysomelid beetle population. Pestic. Sci., 52(4), 361-371.

[147] Kobori, Y., \& Amano, H. (2004). Effects of agrochemicals on life-history parameters of Aphidius gifuensis Ashmead (Hymenoptera: Braconidae). Appl. Entomol. Zool., 39(2), 255-261.

[148] Koehler, H. H. (1997). Mesostigmata (Gamasina, Uropodina), efficient predators in agroecosystems. Agric. Ecosyst. Environ., 62(2-3), 105-117.

[149] Koppenhofer, A. M., Cowles, R. S., Cowles, E. A., Fuzy, E. M., \& Kaya, H. K. (2003). Effect of neonicotinoid synergists on entomopathogenic nematode fitness. Entomol. exp. appl., 106(1), 7-18.

[150] Kreutzweiser, D. P., Good, K. P., Chartrand, D. T., Scarr, T. A., Holmes, S. B., \& Thompson, D. G. (2008). Effects on litter-dwelling earthworms and microbial decomposition of soil-applied imidacloprid for control of wood-boring insects. Pest Manage. Sci., 64(2), 112-118.

[151] Krokene, P. (1993). The effect of an insect growth regulator on grasshoppers (Acrididae) and non-target arthropods in Mali. J. Appl. Entomol., 116(3), 248-266.

[152] Krupke, C. H., Hunt, G. J., Eitzer, B. D., Andino, G., \& Given, K. (2012). Multiple routes of pesticide exposure for honey bees living near agricultural fields. PLoS One, $7(1)$, e29268.

[153] Ku, T. Y., \& Wang, S. C. (1981). Insecticidal resistance of the major insect rice pests, and the effect of insecticides on natural enemies and non-target animals. NTU Phytopathologist and Entomologist [8], 1-18. 
[154] Kumar, B. V., Boomathi, N., Kumaran, N., \& Kuttalam, S. (2010). Non target effect of ethiprole+imidacloprid $80 \mathrm{WG}$ on predators of rice planthoppers. Madras Agric. J., 97(4/6), 153-156.

[155] Kumaran, N., Kumar, B. V., Boomathi, N., Kuttalam, S., \& Gunasekaran, K. (2009). Non-target effect of ethiprole 10 SC to predators of rice planthoppers. Madras Agric. J., 96(1/6), 208-212.

[156] Kunkel, B. A., Held, D. W., \& Potter, D. A. (2001). Lethal and sublethal effects of bendiocarb, halofenozide, and imidacloprid on Harpalus pennsylvanicus (Coleoptera: Carabidae) following different modes of exposure in turfgrass. J. Econ. Entomol., 94(1), 60-67.

[157] Kwon, Y. K., Wee, S. H., \& Kim, J. H. (2004). Pesticide poisoning events in wild birds in Korea from 1998 to 2002. J. Wildl. Dis., 40(4), 737-740.

[158] Lahr, J. (1998). An ecological assessment of the hazard of eight insecticides used in desert locust control, to invertebrates in temporary ponds in the Sahel. Aquat.Ecol., 32(2), 153-162.

[159] Lakshmi, V. J., Krishnaiah, N. V., \& Katti, G. R. (2010). Potential toxicity of selected insecticides to rice leafhoppers and planthoppers and their important natural enemies. J. Biol. Control, 24(3), 244-252.

[160] Langer-Jaesrich, M., Kohler, H. R., \& Gerhardt, A. (2010). Assessing toxicity of the insecticide thiacloprid on Chironomus riparius (Insecta: Diptera) using multiple end points. Arch. Environ. Contam. Toxicol., 58(4), 963-972.

[161] Lannacone, J., Onofre, R., \& Huanquj, O. (2007). Ecotoxicological effects of cartap on Poecilia reticulata "guppy"(Poecilidae) and Paracheirodon innesi "Neon Tetra" (Characidae). Gayana, 71(2), 170-177.

[162] Lanzoni, A., Sangiorgi, L., Luigi, V.d., Consolini, L., Pasqualini, E., \& Burgio, G. (2012). Evaluation of chronic toxicity of four neonicotinoids to Adalia bipunctata L. (Coleoptera: Coccinellidae) using a demographic approach. IOBC/WPRS Bulletin, 74, 211-217.

[163] Lao, W., Tsukada, D., Greenstein, D. J., Bay, S. M., \& Maruya, K. A. (2010). Analysis, occurrence, and toxic potential of pyrethroids, and fipronil in sediments from an urban estuary. Environ. Toxicol. Chem., 29(4), 843-851.

[164] Lee, S. J., Tomizawa, M., \& Casida, J. E. (2003). Nereistoxin and cartap neurotoxicity attributable to direct block of the insect nicotinic receptor/channel. J. Agric. Food Chem., 51(9), 2646-2652.

[165] Lewis, J. L., \& Forschler, B. T. (2010). Impact of five commercial baits containing chitin synthesis inhibitors on the protist community in Reticulitermes flavipes (Isoptera: Rhinotermitidae). Environ. Entomol., 39(1), 98-104. 
[166] Li, X., Bao, C., Yang, D., Zheng, M., Li, X., \& Tao, S. (2010). Toxicities of fipronil enantiomers to the honeybee Apis mellifera L. and enantiomeric compositions of fipronil in honey plant flowers. Environ. Toxicol. Chem., 29(1), 127-132.

[167] Liess, M., \& Beketov, M. (2011). Traits and stress: keys to identify community effects of low levels of toxicants in test systems. Ecotoxicology, 20(6), 1328-1340.

[168] Lim, R. P., \& Wong, M. C. (1986). The effect of pesticides on the population dynamics and production of Stenocypris major Bairo (Ostracoda) in ricefieds. Arch. Hydrobiol., 106(3), 421-427.

[169] Lima, Junior., I.d, S.d., Nogueira, R. F., Bertoncello, T. F., Melo, E., P.d, , Suekane, R., \& Degrande, P. E. (2010). Seletividade de inseticidas sobre o complexo de predadores das pragas do algodoeiro. Pesquisa Agropecuaria Tropical, 40(3), 347-353.

[170] Linder, G., \& Richmond, M. E. (1990). Feed aversion in small mammals as a potential source of hazard reduction for environmental chemicals: agrochemical case studies. Environ. Toxicol. Chem., 9(1), 95-105.

[171] Lisker, E., Ensminger, M., Gill, S., \& Goh, K. (2011). Detections of eleven organophosphorus insecticides and one herbicide threatening Pacific salmonids, Oncorhynchus spp., in California, 1991-2010. Bull. Environ. Contam. Toxicol., 87(4), 355-360.

[172] Liu, Z., Dai, Y., Huang, G., Gu, Y., Ni, J., Wei, H., \& Yuan, S. (2011). Soil microbial degradation of neonicotinoid insecticides imidacloprid, acetamiprid, thiacloprid and imidaclothiz and its effect on the persistence of bioefficacy against horsebean aphid Aphis craccivora Koch after soil application. Pest Manage. Sci., 67(10), 1245-1252.

[173] Loureiro, S., Svendsen, C., Ferreira, A. L. G., Pinheiro, C., Ribeiro, F., \& Soares, A. M. V. M. (2010). Toxicity of three binary mixtures to Daphnia magna: Comparing chemical modes of action and deviations from conceptual models. Environ. Toxicol. Chem., 29(8), 1716-1726.

[174] Lu, C., Warchol, K. M., \& Callahan, R. A. (2012). In situ replication of honey bee colony collapse disorder. Bull. Insectology, 65(1), 99-106.

[175] Lue, L. P., Lewis, C. C., \& Melchor, V. E. (1984). The effect of aldicarb on nematode population and its persistence in carrots, soil and hydroponic solution. J. Environ. Sci. Health B, 19(3), 343-354.

[176] Maccagnani, B., Ferrari, R., Zucchi, L., \& Bariselli, M. (2008). Nei medicai dell'emiliaromagna: difendersi dalle cavallette, ma tutelare le api. Informatore Agrario, 64(25), 53-56.

[177] Magagula, C. N., \& Samways, M. J. (2000). Effects of insect growth regulators on Chilocorus nigritus (Fabricius) (Coleoptera: Coccinellidae), a non-target natural enemy of citrus red scale, Aonidiella aurantii (Maskell) (Homoptera: Diaspididae), in southern Africa: evidence from laboratory and field trials. African Entomol., 8(1), 47-56. 
[178] Malinowski, H. (2006). Bioroznorodnosc a ochrona lasu przed szkodliwymi owadami. Progress in Plant Protection, 46(1), 319-325.

[179] Marletto, F., Patetta, A., \& Manino, A. (2003). Laboratory assessment of pesticide toxicity to bumble bees. Bull. Insectology, 56(1), 155-158.

[180] Martikainen, E., Haimi, J., \& Ahtiainen, J. (1998). Effects of dimethoate and benomyl on soil organisms and soil processes- a microcosm study. Appl. Soil Ecol., 9(1-3), 381-387.

[181] Martins, G. L. M., Toscano, L. C., Tomquelski, G. V., \& Maruyama, W. I. (2009). Inseticidas no controle de Anticarsia gemmatalis (Lepidoptera: Noctuidae) e impacto sobre aranhas predadoras em soja. Revista Brasileira de Ciencias Agrarias, 4(2), 128-132.

[182] Matsumura, F. (1985). Toxicology of Pesticides. Plenum Press 0-306-41979-3, New York, USA.

[183] Maul, J. D., Brennan, A. A., Harwood, A. D., \& Lydy, M. J. (2008). Effect of sedimentasociated pyrethroids, fipronil, and metabolites on Chironomus tentans growth rate, body mass, condition index, immobilization, and survival. Environ. Toxicol. Chem., 27(12), 2582-2590.

[184] Mayer, D. F., \& Lunden, J. D. (1994). Effects of the adjuvant Sylgard 309 on the hazard of selected insecticides to honey bees. Bee Sci., 3(3), 135-138.

[185] Mayer, D. F., Patten, K. D., Macfarlane, R. P., \& Shanks, C. H. (1994). Differences between susceptibility of four pollinator species (Hymenoptera: Apoidea) to field weathered insecticide residues. Melanderia, 50, 24-27.

[186] Medrzycki, P., Montanari, R., Bortolotti, L., Sabatini, A. G., Maini, S., \& Porrini, C. (2003). Effects of imidacloprid administered in sublethal doses on honey bee behaviour. Laboratory tests. Bull. Insectology, 56(1), 59-62.

[187] Meher, H. C., Gajbhiye, V. T., Singh, G., Kamra, A., \& Chawla, G. (2010). Persistence and nematicidal efficacy of carbosulfan, cadusafos, phorate, and triazophos in soil and uptake by chickpea and tomato crops under tropical conditions. J. Agric. Food Chem., 58(3), 1815-1822.

[188] Mesléard, F., Garnero, S., Beck, N., \& Rosecchi, E. (2005). Uselessness and indirect negative effects of an insecticide on rice field invertebrates. Comptes Rendus Biologies, 328(10-11), 955-62.

[189] Mineau, P. (1988). Avian mortality in agroecosystems. I. The case against granule insecticides in Canada. In: Field Methods for the Study of Environmental Effects of Pesticides, Greaves, M.P. et al., editors, British Crop Protection Council, London, 3-12.

[190] Mineau, P., \& Whiteside, M. (2006). Lethal risk to birds from insecticide use in the United States- A spatial and temporal analysis. Environ. Toxicol. Chem., 25(5), 1214-1222. 
[191] Miranda, G. R. B., Raetano, C. G., Silva, E., Daam, M. A., \& Cerejeira, M. J. (2011). Environmental fate of neonicotinoids and classification of their potential risks to hypogean, epygean, and surface water ecosystems in Brazil. Hum. Ecol. Risk Assess., 17(4), 981-995.

[192] Moens, J., Tirry, L., \& Clercq, P.d. (2012). Susceptibility of cocooned pupae and adults of the parasitoid Microplitis mediator to selected insecticides. Phytoparasitica, 40(1), 5-9.

[193] Mommaerts, V., Reynders, S., Boulet, J., Besard, L., Sterk, G., \& Smagghe, G. (2010). Risk assessment for side-effects of neonicotinoids against bumblebees with and without impairing foraging behavior. Ecotoxicology, 19(1), 207-215.

[194] Morandin, L. A., \& Winston, M. L. (2003). Effects of novel pesticides on bumble bee (Hymenoptera: Apidae) colony health and foraging ability. Environ. Entomol., 32(3), 555-563.

[195] Moreby, S. J., Southway, S., Barker, A., \& Holland, J. M. (2001). A comparison of the effect of new and established insecticides on nontarget invertebrates on winter wheat fields. Environ. Toxicol. Chem., 20(10), 2243-2254.

[196] Moser, S. E., \& Obrycki, J. J. (2009). Non-target effects of neonicotinoid seed treatments; mortality of coccinellid larvae related to zoophytophagy. Biol. Control, 51(3), 487-492.

[197] Moser, V. C., Mc Daniel, K. L., Phillips, P. M., \& Lowit, A. B. (2010). Time-course, dose-response, and age comparative sensitivity of N-methyl carbamates in rats. Toxicol. Sci., 114(1), 113-123.

[198] Mosleh, Y. Y., Paris-Palacios, S., Couderchet, M., \& Vernet, G. (2003). Acute and sublethal effects of two insecticides on earthworms (Lumbricus terrestris L.) under laboratory conditions. Environ. Toxicol., 18(1), 1-8.

[199] Moulton, C. A., Flemming, W. J., \& Purnell, C. E. (1996). Effects of two cholinesterase-inhibiting pesticides on freshwater mussels. Environ. Toxicol. Chem., 15(2), 131-137.

[200] Mullin, C. A., Frazier, M., Frazier, J. L., Ashcraft, S., Simonds, R., D.v, E., \& Pettis, J. S. (2010). High levels of miticides and agrochemicals in North American apiaries: implications for honey bee health. PLoS One, 5(3), e9754.

[201] Nakahira, K., Kashitani, R., Tomoda, M., Kodama, R., Ito, K., Yamanaka, S., Momoshita, M., Arakawa, R., \& Takagi, M. (2011). Systemic nicotinoid toxicity against the predatory mirid Pilophorus typicus: residual side effect and evidence for plant sucking. J. Faculty Agric. Kyushu University, 56(1), 53-55.

[202] Naveed, M., Salam, A., Saleem, M. A., Rafiq, M., \& Hamza, A. (2010). Toxicity of thiamethoxam and imidacloprid as seed treatments to parasitoids associated to control Bemisia tabaci. Pakistan J. Zool., 42(5), 559-565. 
[203] Norelius, E., \& Lockwood, J. (1999). The effects of reduced agent-area insecticide treatments for rangeland grasshopper (Orthoptera: Acrididae) control on bird densities. Arch. Environ. Contam. Toxicol., 37(4), 519-528.

[204] Ohnesorg, W. J., Johnson, K. D., \& O’Neal, M. E. (2009). Impact of reduced-risk insecticides on soybean aphid and associated natural enemies. J. Econ. Entomol., 102(5), 1816-1826.

[205] Oldroyd, B. P. (2007). What's killing American honey bees? PLOS Biology, 5(6), e168.

[206] Papachristos, D. P., \& Milonas, P. G. (2008). Adverse effects of soil applied insecticides on the predatory coccinellid Hippodamia undecimnotata (Coleoptera: Coccinellidae). Biol. Control, 47(1), 77-81.

[207] Parker, M., \& Goldstein, M. (2000). Differential toxicities of organophosphate and carbamate insecticides in the nestling European starling (Sturnus vulgaris). Arch. Environ. Contam. Toxicol., 39(2), 233-242.

[208] Patterson, K. (1991). Killing the birds and the bees. Environmental Action, 23(1), 7-8.

[209] Peck, D. C. (2009). Comparative impacts of white grub (Coleoptera: Scarabaeidae) control products on the abundance of non-target soil-active arthropods in turfgrass. Pedobiologia, 52(5), 287-299.

[210] Peck, D. C., \& Olmstead, D. (2010). Neonicotinoid insecticides disrupt predation on the eggs of turf-infesting scarab beetles. Bull. Entomol. Res., 100(6), 689-700.

[211] Pekár, S. (1999). Foraging mode: a factor affecting the susceptibility of spiders (Araneae) to insecticide applications. Pestic. Sci., 55(11), 1077-1082.

[212] Perfecto, I. (1990). Indirect and direct effects in a tropical agroecosystem: the maizepest-ant system in Nicaragua. Ecology, 71(6), 2125-2134.

[213] Pettis, J., van Engelsdorp, D., Johnson, J., \& Dively, G. (2012). Pesticide exposure in honey bees results in increased levels of the gut pathogen Nosema. Naturwissenschaften, 99(2), 153-158.

[214] Peveling, R., Mc William, A. N., Nagel, P., Rasolomanana, H., Raholijaona, Rakotomianina. L., Ravoninjatovo, A., Dewhurst, C. F., Gibson, G., Rafanomezana, S. , et al. (2003). Impact of locust control on harvester termites and endemic vertebrate predators in Madagascar. J. Appl. Ecol., 40(4), 729-741.

[215] Porter, W. P., Green, S. M., Debbink, N. L., \& Carlson, I. (1993). Groundwater pesticides: interactive effects of low concentrations of carbamates aldicarb and methomyl and the triazine metribuzin of thyroxine and somatotropin levels in white rats. J. Toxicol. Environ. Health, 40(1), 15-34.

[216] Potter, D. A., Buxton, M. C., Redmond, C. T., Patterson, C. G., \& Powelu, A. J. (1990). Toxicity of pesticides to earthworms (Oligochaeta: Lumbricidae) and effect on thatch degradation in Kentucky bluegrass turf. J. Econ. Entomol., 83(6), 2362-2369. 
[217] Potts, G. R. (1986). The Partridge - Pesticides, Predation and Conservation. Collins, London, UK.

[218] Pozzebon, A., Duso, C., Tirello, P., \& Ortiz, P. B. (2011). Toxicity of thiamethoxam to Tetranychus urticae Koch and Phytoseiulus persimilis Athias-Henriot (Acari Tetranychidae, Phytoseiidae) through different routes of exposure. Pest Manage. Sci., 67(3), 352-359.

[219] Prabhaker, N., Castle, S., Byrne, F., Henneberry, T. J., \& Toscano, N. C. (2006). Establishment of baseline susceptibility data to various insecticides for Homalodisca coagulata (Homoptera: Cicadellidae) by comparative bioassay techniques. J. Econ. Entomol., 99(1), 141-154.

[220] Preetha, G., Manoharan, T., Stanley, J., \& Kuttalam, S. (2010a). Impact of chloronicotinyl insecticide, imidacloprid on egg, egg-larval and larval parasitoids under laboratory conditions. J. Plant Protection Res., 50(4), 535-540.

[221] Preetha, G., Stanley, J., Suresh, S., \& Samiyappan, R. (2010b). Risk assessment of insecticides used in rice on miridbug, Cyrtorhinus lividipennis Reuter, the important predator of brown planthopper, Nilaparvata lugens (Stal.). Chemosphere, 80(5), 498-503.

[222] Printes, L. B., \& Callaghan, A. (2004). A comparative study on the relationship between acetylcholinesterase activity and acute toxicity in Daphnia magna exposed to acetylcholineesterase insecticides. Environ. Toxicol. Chem., 23(5), 1241-1247.

[223] Qin, G. Q., Presley, S. M., Anderson, T. A., Gao, W. M., \& Maul, J. D. (2011). Effects of predator cues on pesticide toxicity: toward an understanding of the mechanism of the interaction. Environ. Toxicol. Chem., 30(8), 1926-1934.

[224] Rainwater, T. R., Leopold, V. A., Hooper, M. J., \& Kendall, R. J. (1995). Avian exposure to organophosphorous and carbamate pesticides on a coastal South Carolina golf course. Environ. Toxicol. Chem., 14(12), 2155-2161.

[225] Ram, S., \& Gupta, G. P. (1994). Bioefficacy of systemic insecticides against target pest jassid (Amrasca devastans) and their impact on non-target soil microarthropods in cotton (Gossypium spp.). Indian J. Entomol., 56(4), 313-321.

[226] Redoan, A. C., Carvalho, G. A., Cruz, I., Figueiredo, M.d. L. C., \& Silva, R. B.d. (2010). Efeito de inseticidas usados na cultura do milho (Zea mays L.) sobre ninfas e adultos de Doru luteipes (Scudder) (Dermaptera: Forficulidae) em semicampo. Revista Brasileira de Milho e Sorgo, 9(3), 223-235.

[227] Rodrigues, E.d. L., \& Fanta, E. (1998). Liver histopathology of the fish Brachydanio rerio Hamilton-Buchman after acute exposure to sublethal levels of the organophosphate dimethoate 500. Revista Brasileira de Zoologia, 15(2), 441-450.

[228] Rortais, A., Arnold, G., Halm, M. P., \& Touffet-Briens, F. (2005). Modes of honeybees exposure to systemic insecticides: estimated amounts of contaminated pollen and nectar consumed by different categories of bees. Apidologie, 36(1), 71-83. 
[229] Rudolph, S. G., Zinkl, J. G., Anderson, D. W., \& Shea, P. J. (1984). Prey-capturing ability of American kestrels fed DDE and acephate or acephate alone. Arch. Environ. Contam. Toxicol., 13, 367-372.

[230] Rust, M. K., \& Saran, R. K. (2008). Toxicity, repellency, and effects of acetamiprid on western subterranean termite (Isoptera: Rhinotermitidae). J. Econ. Entomol., 101(4), 1360-1366.

[231] Saber, M. (2011). Acute and population level toxicity of imidacloprid and fenpyroximate on an important egg parasitoid, Trichogramma cacoeciae (Hymenoptera: Trichogrammatidae). Ecotoxicology, 20(6), 1476-1484.

[232] San, Miguel. A., Raveton, M., Lemperiere, G., \& Ravanel, P. (2008). Phenylpyrazoles impact on Folsomia candida (Collembola). Soil Biol. Biochem., 40(9), 2351-2357.

[233] Sánchez, Meza. J. C., Avila, Perez. P., Borja, Salin. M., Pacheco, Salazar. V. F., \& Lapoint, T. (2010). Inhibition of cholinesterase activity by soil extracts and predicted environmental concentrations (PEC) to select relevant pesticides in polluted soils. $J$. Environ. Sci. Health B, 45(3), 214-221.

[234] Sánchez-Bayo, F. (2009). From simple toxicological models to prediction of toxic effects in time. Ecotoxicology, 18(3), 343-354.

[235] Sánchez-Bayo, F. (2012). Insecticides mode of action in relation to their toxicity to non-target organisms. J. Environ. Anal. Toxicol., S4, S4-002.

[236] Sánchez-Bayo, F., \& Goka, K. (2005). Unexpected effects of zinc pyrithione and imidacloprid on Japanese medaka fish (Oryzias latipes). Aquat. Toxicol., 74(4), 285-293.

[237] Sánchez-Bayo, F., \& Goka, K. (2006). Ecological effects of the insecticide imidacloprid and a pollutant from antidandruff shampoo in experimental rice fields. Environ. Toxicol. Chem., 25(6), 1677-1687.

[238] Sánchez-Bayo, F., Yamashita, H., Osaka, R., Yoneda, M., \& Goka, K. (2007). Ecological effects of imidacloprid on arthropod communities in and around a vegetable crop. J. Environ. Sci. Health B, 42(3), 279-286.

[239] Schaefer, C. H., Miura, T., Dupras, E. F. Jr, Wilder, W. H., \& Mulligan, F. S. III. (1988). Efficacy of CME 134 against mosquitoes (Diptera: Culicidae): effects on nontarget organisms and evaluation of potential chemical persistence. J. Econ. Entomol., 81(4), 1128-1132.

[240] Schmuck, R. (2004). Effects of a chronic dietary exposure of the honeybee Apis mellifera (Hymenoptera: Apidae) to imidacloprid. Arch. Environ. Contam. Toxicol., 47(4), 471-478.

[241] Schmuck, R., Schöning, R., Stork, A., \& Schramel, O. (2001). Risk posed to honeybees (Apis mellifera L, Hymenoptera) by an imidacloprid seed dressing of sunflowers. Pest Manage. Sci., 57(3), 225-238. 
[242] Schmuck, R., Stadler, T., \& Schmidt, H. W. (2003). Field relevance of a synergistic effect observed in the laboratory between an EBI fungicide and a chloronicotinyl insecticide in the honeybee (Apis mellifera L, Hymenoptera). Pest Manage. Sci., 59(3), 279-286.

[243] Schneider, F. (1966). Some pesticide-wildlife problems in Switzerland. J. Appl. Ecol., 3, 15-20.

[244] Sechser, B., \& Freuler, J. (2003). The impact of thiamethoxam on bumble bee broods (Bombus terrestris L.) following drip application in covered tomato crops. Anzeiger fur Schadlingskunde, 76(3), 74-77.

[245] Sétamou, M., Rodriguez, D., Saldana, R., Schwarzlose, G., Palrang, D., \& Nelson, S. D. (2010). Efficacy and uptake of soil-applied imidacloprid in the control of Asian citrus psyllid and a citrus leafminer, two foliar-feeding citrus pests. J. Econ. Entomol., 103(5), 1711-9.

[246] Sharma, D. R. (2010). Bioefficacy of insecticides against peach leaf curl aphid, Brachycaudus helichrysi (Kaltenbach) in Punjab. Indian J. Entomol., 72(3), 217-222.

[247] Shi, X., Jiang, L., Wang, H., Qiao, K., Wang, D., \& Wang, K. (2011). Toxicities and sublethal effects of seven neonicotinoid insecticides on survival, growth and reproduction of imidacloprid-resistant cotton aphid, Aphis gossypii. Pest Manage. Sci., 67(12), 1528-1533.

[248] Shimoda, T., Yara, K., \& Kawazu, K. (2011). The effects of eight insecticides on the foraging behavior of the parasitoid wasp Cotesia vestalis. J. Plant Interact., 6(2/3), 189-190.

[249] Simpson, I. C., Roger, P. A., Oficial, R., \& Grant, I. F. (1994). Effects of nitrogen fertiliser and pesticide management on floodwater ecology in a wetland ricefield. Biol. Fertil. Soils, 18(3), 219-227.

[250] Smelt, J. H., Crum, S. J. H., Teunissen, W., \& Leistra, M. (1987). Accelerated transformation of aldicarb, oxamyl and ethoprophos after repeated soil treatments. Crop Protection, 6(5), 295-303.

[251] Smith, S. F., \& Krischik, V. A. (1999). Effects of systemic imidacloprid on Coleomegilla maculata (Coleoptera: Coccinellidae). Environ. Entomol., 28(6), 1189-1195.

[252] Sokolov, I. M. (2000). How does insecticidal control of grasshoppers affect non-target arthropods?

[253] Song, M. Y., \& Brown, J. J. (2006). Influence of fluctuating salinity on insecticide tolerance of two euryhaline arthropods. J. Econ. Entomol., 99(3), 745-751.

[254] Sprague, L. A., \& Nowell, L. H. (2008). Comparison of pesticide concentrations in streams at low flow in six metropolitan areas of the United States. Environ. Toxicol. Chem., 27(2), 288-298. 
[255] Srinivas, K., \& Madhumathi, T. (2005). Effect of insecticide applications on the predator population in rice ecosystem of Andhra Pradesh. Pest Manage. Econ. Zool., 13(1), 71-75.

[256] Stadler, T., Martinez, Gines. D., \& Buteler, M. (2003). Long-term toxicity assessment of imidacloprid to evaluate side effects on honey bees exposed to treated sunflower in Argentina. Bull. Insectology, 56(1), 77-81.

[257] Stapel, J. O., Cortesero, A. M., \& Lewis, W. J. (2000). Disruptive sublethal effects of insecticides on biological control: altered foraging ability and life span of a parasitoid after feeding on extrafloral nectar of cotton treated with systemic insecticides. Biol. Control, 17, 243-249.

[258] Stara, J., Ourednickova, J., \& Kocourek, F. (2011). Laboratory evaluation of the side effects of insecticides on Aphidius colemani (Hymenoptera: Aphidiidae), Aphidoletes aphidimyza (Diptera: Cecidomyiidae), and Neoseiulus cucumeris (Acari: Phytoseidae). J. Pest Sci., 84(1), 25-31.

[259] Stark, J., \& Vargas, R. (2005). Toxicity and hazard assessment of fipronil to Daphnia pulex Ecotoxicol. Environ. Saf. , 62(1), 11-16.

[260] Stark, J. D., Banks, J. E., \& Vargas, R. (2004). How risky Is risk assessment: the role that life history strategies play in susceptibility of species to stress. PNAS, 101(3), 732-736.

[261] Starner, K., \& Goh, K. (2012). Detections of the neonicotinoid insecticide imidacloprid in surface waters of three agricultural regions of California, USA, 2010-2011. Bull. Environ. Contam. Toxicol., 88(3), 316-321.

[262] Steinbauer, M. J., \& Peveling, R. (2011). The impact of the locust control insecticide fipronil on termites and ants in two contrasting habitats in northern Australia. Crop Protection, 30(7), 814-825.

[263] Sterk, G., \& Benuzzi, M. (2004). Nuovi fitofarmaci, prove di tossicita sui bombi in serra. Colture Protette, 33(1), 75-77.

[264] Stevens, M. M., Burdett, A. S., Mudford, E. M., Helliwell, S., \& Doran, G. (2011). The acute toxicity of fipronil to two non-target invertebrates associated with mosquito breeding sites in Australia. Acta Tropica, 117(2), 125-130.

[265] Stoughton, Sarah. J., Karsten, Liber., Joseph, Culp., \& Allan, Cessna. (2008). Acute and chronic toxicity of imidacloprid to the aquatic invertebrates Chironomus tentans and Hyalella azteca under constant- and pulse-exposure conditions. Arch. Environ. Contam. Toxicol., 54(4), 662-673.

[266] Suchail, S., Guez, D., \& Belzunces, L. P. (2001). Discrepancy between acute and chronic toxicity induced by imidacloprid and its metabolites in Apis mellifera. Environ. Toxicol. Chem., 20(11), 2482-2486. 
[267] Sugiyama, K., Katayama, H., \& Saito, T. (2011). Effect of insecticides on the mortalities of three whitefly parasitoid species, Eretmocerus mundus, Eretmocerus eremicus and Encarsia formosa (Hymenoptera: Aphelinidae). Appl. Entomol. Zool., 46(3), 311-317.

[268] Szczepaniec, A., Creary, S. F., Laskowski, K. L., Nyrop, J. P., \& Raupp, M. J. (2011). Neonicotinoid insecticide imidacloprid causes outbreaks of spider mites on elm trees in urban landscapes. PLoS One, 6(5), e20018.

[269] Szendrei, Z., Grafius, E., Byrne, A., \& Ziegler, A. (2012). Resistance to neonicotinoid insecticides in field populations of the Colorado potato beetle (Coleoptera: Chrysomelidae). Pest Manage. Sci., 68(6), 941-946.

[270] Takada, Y., Kawamura, S., \& Tanaka, T. (2001). Effects of various insecticides on the development of the egg parasitoid Trichogramma dendrolimi (Hymenoptera: Trichogrammatidae). J. Econ. Entomol., 94(6), 1340-1343.

[271] Tanaka, T., \& Minakuchi, C. (2011). Insecticides and parasitoids. In: Insecticides- Advances in Integrated Pest Management, Perveen, F., editor, InTech, Rijeka, Croatia, 115-140.

[272] Tapparo, A., Giorio, C., Marzaro, M., Marton, D., Solda, L., \& Girolami, V. (2011). Rapid analysis of neonicotinoid insecticides in guttation drops of corn seedlings obtained from coated seeds. J. Environ. Monit., 13(6), 1564-1568.

[273] Teeters, B. S., Johnson, R. M., Ellis, M. D., \& Siegfried, B. D. (2012). Using video-tracking to assess sublethal effects of pesticides on honey bees (Apis mellifera L.). Environ. Toxicol. Chem., 31(6), 1349-1354.

[274] Tennekes, H. A. (2010a). The significance of the Druckrey-Küpfmüller equation for risk assessment - The toxicity of neonicotinoid insecticides to arthropods is reinforced by exposure time. Toxicology, 276(1), 1-4.

[275] Tennekes, H. A. (2010b). The Systemic Insecticides: A Disaster in the Making. ETS Nederland BV, Zutphen, The Netherlands. 978-90-79627-06-6

[276] Tennekes, H. A., \& Sánchez-Bayo, F. (2012). Time-dependent toxicity of neonicotinoids and other toxicants: implications for a new approach to risk assessment. J. Environ. Anal. Toxicol., S4, S4-001.

[277] Thacker, J. R. M., \& Jepson, P. C. (1993). Pesticide risk assessment and non-target invertebrates: integrating population depletion, population recovery, and experimental design. Bull. Environ. Contam. Toxicol., 51(4), 523-531.

[278] Thomazoni, D., Soria, M. F., Kodama, C., Carbonari, V., Fortunato, R. P., Degrande, P. E., \& Valter, Junior. V. A. (2009). Selectivity of insecticides for adult workers of Apis mellifera (Hymenoptera: Apidae). Revista Colombiana de Entomologia, 35(2), 173-176. 
[279] Thompson, H., Walker, C., \& Hardy, A. (1991). Changes in activity of avian serum esterases following exposure to organophosphorus insecticides. Arch. Environ. Contam. Toxicol., 20(4), 514-518.

[280] Thornton, M., Miller, J., Hutchinson, P., \& Alvarez, J. (2010). Response of potatoes to soil-applied insecticides, fungicides, and herbicides. Potato Research, 53(4), 351-358.

[281] Tian, H., Ru, S., Bing, X., \& Wang, W. (2010). Effects of monocrotophos on the reproductive axis in the male goldfish (Carassius auratus): potential mechanisms underlying vitellogenin induction. Aquat. Toxicol., 98(1), 67-73.

[282] Tian, J., Chen, Y., Li, Z., Peng, Y., \& Ye, G. (2011). Assessment of effect of transgenic rice with cry $1 \mathrm{Ab}$ gene and two insecticides on immune of non-target natural enemy, Pardosa pseudoannulata. Chinese J. Biol. Control , 27(4), 559-563.

[283] Tomizawa, M., Lee, D. L., \& Casida, J. E. (2000). Neonicotinoid insecticides: molecular features conferring selectivity for insect versus mammalian nicotinic receptors. $J$. Agric. Food Chem., 48(12), 6016-6024.

[284] Tomlin, C. D. S. (2009). The e-Pesticide Manual. Tomlin, C.D.S.,editor. 12 ed. Surrey, U.K.: British Crop Protection Council.

[285] Tremolada, P., Mazzoleni, M., Saliu, F., Colombo, M., \& Vighi, M. (2010). Field trial for evaluating the effects on honeybees of corn sown using cruiser ${ }^{\circledR}$ and Celest (RTreated Seeds. Bull. Environ. Contam. Toxicol., 85(3), 229-234.

[286] Turner, A. S., Bale, J. S., \& Clements, R. O. (1987). The effect of a range of pesticides on non-target organisms in the grassland environment. Proceedings, Crop Protection in Northern Britain ‘87, Dundee University, 15-17 March., 290-295.

[287] van Dijk, T. C. (2010). Effects of neonicotinoid pesticide pollution of Dutch surface water on non-target species abundance. Universiteit Utrecht., 77.

[288] Van Gestel, C. A. M. (1992). Validation of earthworm toxicity tests by comparison with field studies: a review of benomyl, carbendazim, carbofuran, and carbaryl. Ecotoxicol. Environ. Saf., 23, 221-236.

[289] van Timmeren, S., Wise, J. C., \& Isaacs, R. (2012). Soil application of neonicotinoid insecticides for control of insect pests in wine grape vineyards. Pest Manage. Sci., 68(4), 537-542.

[290] Vasuki, V. (1992). Sublethal effects of hexaflumuron, an insect growth regulator, on some non-target larvivorous fishes. Indian J. Exp. Biol. , 30(12), 1163-1165.

[291] Verghese, A. (1998). Effect of imidacloprid on mango hoppers, Idioscopus spp. (Homoptera: Cicadellidae). Pest Manage. Hort. Ecosyst., 4(2), 70-74.

[292] Vernon, R. S., Herk, W.v., Tolman, J., Saavedra, H. O., Clodius, M., \& Gage, B. (2008). Transitional sublethal and lethal effects of insecticides after dermal exposures to five economic species of wireworms (Coleoptera: Elateridae). J. Econ. Entomol., 101(2), 365-374. 
[293] Vidau, C., Diogon, M., Aufauvre, J., Fontbonne, R., Vigues, B., Brunet, J. L., Texier, C., Biron, D. G., Blot, N., El -Alaoui, H., et al. (2011). Exposure to sublethal doses of fipronil and thiacloprid highly increases mortality of honeybees previously infected by Nosema ceranae. PLoS One(June), e21550.

[294] Vogt, H., Just, J., \& Grutzmacher, A. (2009). Einfluss von Insektiziden im Obstbau auf den Ohrwurm Forficula auricularia. Mitteilungen der Deutschen Gesellschaft fur allgemeine und angewandte Entomologie, 17, 211-214.

[295] Vyas, N. B., Kuenzel, W. J., Hill, E. F., \& Sauer, J. R. (1995). Acephate affects migratory orientation of the white-throated sparrow (Zonotrichia albicollis). Environ. Toxicol. Chem., 14(11), 1961-1965.

[296] Wada, S., \& Toyota, K. (2008). Effect of three organophosphorous nematicides on non-target nematodes and soil microbial community. Microbes and Environments, 23(4), 331-336.

[297] Walker, C. H., Hopkin, S. P., Sibly, R. M., \& Peakall, D. B. (2001). Principles of Ecotoxicology. 2nd), Taylor \& Francis, Glasgow, UK.0-7484-0940-8

[298] Walker, M. K., Stufkens, M. A. W., \& Wallace, A. R. (2007). Indirect non-target effects of insecticides on Tasmanian brown lacewing (Micromus tasmaniae) from feeding on lettuce aphid (Nasonovia ribisnigri). Biol. Control, 43(1), 31-40.

[299] Wang, Y., Yu, R., Zhao, X., An, X., Chen, L., Wu, C., \& Wang, Q. (2012). Acute toxicity and safety evaluation of neonicotinoids and macrocyclic lactiones to adult wasps of four Trichogramma species (Hymenoptera: Trichogrammidae). Acta Entomologica Sinica, 55(1), 36-45.

[300] Way, M. J., \& Scopes, N. E. A. (1968). Studies on the persistence and effects on soil fauna of some soil-applied systemic insecticides. Ann. Appl. Biol., 62, 199-214.

[301] Webster, T. C., \& Peng, Y. S. (1989). Short-term and long-term effects of methamidophos on brood rearing in honey bee (Hymenoptera: Apidae) colonies. J. Econ. Entomol., 82(1), 69-74.

[302] White, D. H., \& Segmak, J. T. (1990). Brain cholinesterase inhibition in songbirds from pecan groves sprayed with phosalone and disulfoton. J. Wildl. Dis., 26, 103-106.

[303] Wirth, E. F., Pennington, P. L., Lawton, J. C., De Lorenzo, M. E., Bearden, D., Shaddrix, B., Sivertsen, S., \& Fulton, M. H. (2004). The effects of the contemporary-use insecticide (fipronil) in an estuarine mesocosm. Environ. Pollut., 131(3), 365-371.

[304] Yang, E. C., Chuang, Y. C., Chen, Y. L., \& Chang, L. H. (2008). Abnormal foraging behavior induced by sublethal dosage of imidacloprid in the honey bee (Hymenoptera: Apidae). J. Econ. Entomol., 101(6), 1743-1748.

[305] Yen, J. H., Lin, K. H., \& Wang, Y. S. (2000). Potential of the insecticides acephate and methamidophos to contaminate groundwater. Ecotoxicol. Environ. Saf., 45(1), 79-86. 
[306] Zang, Y., Zhong, Y., Luo, Y., \& Kong, Z. M. (2000). Genotoxicity of two novel pesticides for the earthworm, Eisenia fetida. Environ. Pollut., 108(2), 271-278.

[307] Zhang, A., Kaiser, H., Maienfisch, P., \& Casida, J. E. (2000). Insect nicotinic acetylcholine receptor: conserved neonicotinoid specificity of $[3 \mathrm{H}]$ imidacloprid binding site. J. Neurochem., 75(3), 1294-1303.

[308] Zhou, S., Dong, Q., Li, S., Guo, J., Wang, X., \& Zhu, G. (2009). Developmental toxicity of cartap on zebrafish embryos. Aquat. Toxicol., 95(4), 339-346. 